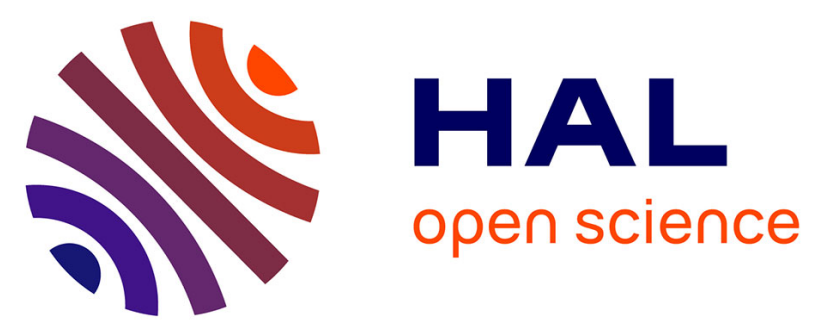

\title{
Basement-cover decoupling during the inversion of a hyperextended basin: Insights from the Eastern Pyrenees
}

\author{
Maxime Ducoux, Laurent Jolivet, F. Cagnard, T. Baudin
}

\section{To cite this version:}

Maxime Ducoux, Laurent Jolivet, F. Cagnard, T. Baudin. Basement-cover decoupling during the inversion of a hyperextended basin: Insights from the Eastern Pyrenees. Tectonics, 2021, 40 (5), pp.e2020TC006512. 10.1029/2020TC006512 . insu-03207683

\section{HAL Id: insu-03207683 \\ https://hal-insu.archives-ouvertes.fr/insu-03207683}

Submitted on 26 Apr 2021

HAL is a multi-disciplinary open access archive for the deposit and dissemination of scientific research documents, whether they are published or not. The documents may come from teaching and research institutions in France or abroad, or from public or private research centers.
L'archive ouverte pluridisciplinaire HAL, est destinée au dépôt et à la diffusion de documents scientifiques de niveau recherche, publiés ou non, émanant des établissements d'enseignement et de recherche français ou étrangers, des laboratoires publics ou privés. 


\section{from the Eastern Pyrenees}

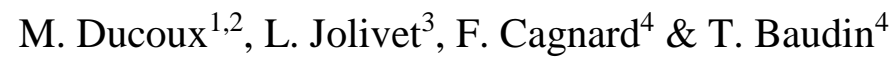

4

${ }^{1}$ ISTO, UMR7327, Université d'Orléans, CNRS, BRGM, F-45071 Orléans, France,

5

${ }^{2}$ Now at : M\&U Sasu, 38120 SAINT-EGREVE, France

${ }^{3}$ Sorbonne Université, CNRS-INSU, Institut des Sciences de la Terre Paris, ISTeP UMR 7193, F-75005 Paris, France

${ }^{4}$ BRGM, F-45060 Orléans, France,

\section{Abstract}

10 Deformation processes related to early stages of collisional belts, especially the inversion of

11 rifted systems remain poorly constrained, partly because evidence of these processes is usually

12 obliterated during the subsequent collision. The Pyrenean belt resulting from the inversion of a Cretaceous hyperextended rifted margin associated with a HT/LP metamorphism in the Internal Metamorphic Zone (IMZ), is a good example for studying the early stage of orogenic deformation. This study is focused on the Eastern Pyrenees where the relation between inverted

iv Iesozoic rifted basins and their basement are well-preserved. By using maximum temperatures

17 ( $\left.T_{\max }\right)$ estimated by the Raman Spectroscopy of Carbonaceous Materials geothermometer and 18 structural data, we describe the spatial distribution of the various tectono-metamorphic units. $T_{\max }$ recorded in the sedimentary cover exposed to the north and to the south of a Paleozoic

20 basement block (Agly massif), exceed $550^{\circ} \mathrm{C}$, while the Paleozoic metasediments and their

21 autochthonous Mesozoic cover show $T_{\max }<350^{\circ} \mathrm{C}$. The metamorphic sedimentary cover is .L affected by ductile deformation, while the basement is only affected by brittle deformation.

23 Post-metamorphism breccias are observed between the basement and the metamorphic This article has been accepted for publication and undergone full peer review but has not been through the copyediting, typesetting, pagination and proofreading process, which may lead to differences between this version and the Version of Record. Please cite this article as doi: 10.1029/2020TC006512.

This article is protected by copyright. All rights reserved. 
sedimentary cover, which are interpreted as a decollement level in the Upper Triassic evaporites. Unlike previous models suggesting that the basement block separated two metamorphic basins (Boucheville and Bas Agly) during rifting, we propose a large displacement of a single metamorphic basin by a large thrust above the basement block. This novel interpretation emphasizes the general allochthonous position of the former hyperextended rift basin (IMZ) thrusted along a decoupling layer.

\section{Introduction}

It is commonly accepted that the major part of collisional orogens often results from the inversion and contraction of former continental rifted margins. However, the early stages of orogenic processes, corresponding to the inversion of the rifted system, usually affected by hyperextension, remains poorly constrained. The lack of knowledge on the early orogenic processes stems from the obliteration of the hyperextended part of former rift systems, during collision, by a strong metamorphic and tectonic overprint or because this domain is now buried in the crustal root of belts. Therefore, the inherited rift-related geometries and thermalmechanical structure of the pre-orogenic crust and lithosphere play important roles in the structural style of collisional orogens (e.g. Lemoine et al., 1986; Watts et al., 1995; Mouthereau et al., 2013; Jammes \& Huismans, 2012; Manatschal et al., 2015). Reconstructing the evolution of collisional belts and especially quantifying the finite shortening requires a precise understanding of their overall structure and kinematics, including the pre-orogenic position of the thrust packages. Recent studies have shown that the occurrence of salt tectonics during the pre-orogenic period can lead to significant overestimation of finite orogenic shortening (e.g. Jourdon et al., 2020; Izquierdo-Llavall et al., 2020; Labaume \& Teixell, 2020). The timing of deposition of weak layers (salt-bearing rocks or shales), pre-, syn- or post-rift, is thus one of the main factors that controls the overall architecture and the structural patterns of rifted basins (e.g. Jackson and Vendeville, 1994; Rowan, 2014; Duretz et al., 2019; Jourdon et al., 2019,

This article is protected by copyright. All rights reserved. 
2020). When the decoupling layer is pre-rift, it may act as a decollement layer leading to the partitioning of the deformation between the basement and overburden units during rifting (e.g. Jammes et al., 2010; Rowan, 2014; Ducoux et al., 2019; Coleman et al., 2019; Izquierdo-Llavall et al., 2020; Labaume \& Teixell, 2020). During contractional deformation, pre-rift weak layers control the geometry of the thrust belt by favoring strain propagation toward the foreland thinskinned tectonics (e.g. Letouzey et al., 1995; Jourdon et al., 2020).

The Pyrenean orogen (Fig. 1) results from the inversion and integration of a Lower Cretaceous hyperextended rift system with a pre-rift Triassic evaporitic layer (Lagabrielle and Bodinier, 2008; Jammes et al., 2009; Lagabrielle et al., 2010; Clerc et al., 2012, 2013; Clerc and Lagabrielle, 2014; Masini et al., 2014; Tugend et al., 2014; Lagabrielle et al., 2016; Clerc et al., 2016, Duretz et al., 2019; Jourdon et al., 2019, 2020). This crustal thinning episode was associated with a high-temperature and low-pressure (HT/LP) metamorphic event observed within narrow stripes on the south edge of North Pyrenean Zone (NPZ), forming the so-called Internal Metamorphic Zone (IMZ), where pre- to syn-rift sediments display a HT/LP metamorphism up to $600^{\circ} \mathrm{C}$ and below 4kbar (Bernus-Maury, 1984; Golberg and Leyreloup, 1990; Vauchez et al., 2013; Clerc et al., 2015). The NPZ domain is limited by major crustal faults, the North Pyrenean Frontal Thrust in the north and the North Pyrenean Fault along the southern rim, considered as a major discontinuity between two lithospheric plates and assumed to be active since the end of the Variscan orogenic cycle (Mattauer, 1968; Choukroune, 1976; Choukroune and Mattauer, 1978; Choukroune and ECORS Team, 1989).

Several studies investigated the tectonic evolution of Pyrenean belt and proposed estimates of the finite shortening based on N-S balanced geological sections (Choukroune and ECORSPyrenees Team, 1989; Roure et al., 1989; Muñoz, 1992; Teixell, 1998; Vergés et al., 2002; Martinez-Peña and Casas-Sainz, 2003; Beaumont et al., 2000; Mouthereau et al., 2014; Teixell et al., 2016; Ternois et al., 2019) but the role of decoupling layer and the early orogenic This article is protected by copyright. All rights reserved. 
processes were not assessed in details in these reconstructions. Only a few previous works

75 described the early orogenic stages, suggesting the formation of an accretionary prism by the

76 inversion of the former distal part of the rift system (Mouthereau et al., 2014; Ford et al., 2016).

77 A recent study in the Western Pyrenees demonstrated that the early orogenic stage was associated with the inversion of the hyperextended rift system, reactivating rift-related extensional structures (Gomez-Romeu et al., 2019). In addition, the thick pre-rift Triassic evaporites, which had induced salt-tectonics during the Cretaceous rifting and gravity-driven post-rift deformation (e.g. Lopez-Mir et al., 2014; Saura et al., 2016; Teixell et al., 2016) acted as a decollement during the subsequent Pyrenean shortening (Canérot, 1988; Canérot et

83 Lenoble, 1993; James \& Canérot, 1999; Canérot, 2008; Ferrer et al., 2009 ; Jammes et al.,

842009 ; 2010; Ducoux et al., 2019; Labaume \& Teixell, 2020; Izquierdo-Llavall et al., 2020).

85 The geometry of syn-rift structures is then difficult to assess because the former Cretaceous hyperextended rift basins were strongly overprinted by collisional deformation, except in the western and eastern Pyrenees. In particular, in the eastern Pyrenees, extension led to intense crustal boudinage and decoupling of the sedimentary cover from the basement (Clerc and Lagabrielle, 2014; Clerc et al., 2016). In this area, we have access to a complete section across

90 basins which belonged to the former distal portion of the rift system, making this region a good 91 candidate to study early orogenic processes corresponding to the inversion of the hyperextended 92 rift basins.

93 By using new maximum temperature $\left(T_{\max }\right)$ reached by sedimentary rocks and structural data, 94 the aim of this study is to reconsider the bulk structure of the NE portion of the eastern Pyrenees 95 and investigate the role of a pre-rift weak evaporitic layer in the partitioning of the deformation 96 during contractional deformation. In the eastern Pyrenees, published rift restorations suggest 97 that the Agly massif was a high separating two basins (Vauchez et al., 2013; Clerc et al., 2015; 98 2016; Ternois et al., 2019; Odlum and Stockli, 2019); (1) the Boucheville basin sits on the rift This article is protected by copyright. All rights reserved. 
axis above exhumed lithospheric mantle, and (2) the Bas-Agly/St-Paul-de-Fenouillet basin sits

100 on hyperthinned to thinned continental crust. This architecture is questionable, because it does

101 not explain the HT/LP metamorphism observed in the present-day Bas-Agly syncline with

102 temperatures similar to the Boucheville Basin, nor the low-temperature recorded in the St-Paul-

103 de-Fenouillet syncline. We propose that the IMZ is allochthonous on top of the Agly North

104 Pyrenean massif and its sedimentary cover and that the Bas-Agly syncline is a northern klippe

105 of the IMZ. This interpretation suggests that the amount of Mesozoic sedimentary unit

106 displacement in the eastern Pyrenees may be larger than classically proposed. In this work, we

107 describe the succession of events that produce the present-day Pyrenean geometries, from the

108 Late Cretaceous rifting stage to the Cenozoic main horizontal shortening, showing how the syn-

109 rift geometry was reworked and how it controlled the finite structure of the belt.

\section{Geological setting}

2.1. The Pyrenean belt

112 The Pyrenean belt results from the collision between the Eurasian and Iberian plates from late

113 Cretaceous to Miocene time. The present structure of the Pyrenean belt shows an asymmetric

114 double-verging tectonic wedge above the northward underthrusting Iberian continental

115 lithosphere (Choukroune and ECORS Team, 1989; Roure et al., 1989; Muñoz, 1992; Vergés et

116 al., 1995; Teixell, 1998; Teixell et al., 2016; Chevrot et al., 2018). Across a maximum width of

$117150 \mathrm{~km}$, the Pyrenees are traditionally divided into five distinct structural domains (Bertrand,

118 1940; Mattauer, 1968; Choukroune \& Séguret, 1973; Castéras, 1974; Mattauer \& Henry, 1974;

119 Mirouse, 1980; Boillot, 1984) (Figure 1). (1) The Ebro and (2) the Aquitaine basins respectively

120 correspond to the foreland and retro-foreland basins (e.g. Ford et al., 2016; Angrand et al.,

121 2018). (3) The NPZ is a WNW-ESE elongated ribbon made of thrusts and folds deforming the

122 Mesozoic sedimentary succession of Cretaceous basins and locally associated with basement

123 blocks (North Pyrenean massifs). The NPZ is limited by the North Pyrenean Frontal Thrust

This article is protected by copyright. All rights reserved. 
124 (NPFT) and the North Pyrenean Fault. (4) The Axial Zone, the topographic backbone of the

125 Pyrenees, is mainly composed of Paleozoic rocks deformed during the Variscan and Alpine 126 orogenic cycles (Mattauer, 1964; Mattauer and Seguret, 1966; Debat, 1969). Finally, (5) the

127 South Pyrenean Zone (SPZ) consists of Mesozoic to Eocene sedimentary rocks transported 128 southward over the Ebro basin above the South Pyrenean Frontal Thrust (SPFT) localized 129 within the Triassic evaporites (Séguret, 1972; Vergés and Muñoz, 1990; López-Mir et al., $130 \quad 2014)$.

131 The architecture of the Pyrenees results from the inversion and integration in the orogen of early 132 Aptian to early Cenomanian rifted basins (Lagabrielle and Bodinier, 2008; Jammes et al., 2009, 133 2010; Lagabrielle et al., 2010; Clerc et al., 2012, 2013; Masini et al., 2014; Tugend et al., 2014;

134 Lagabrielle et al., 2016). Rifting has then evolved to hyperextension and mantle exhumation in 135 the NPZ and the Basque-Cantabrian Basin as suggested by several mantle exposures, then to 136 drifting further west in the Bay of Biscay (e.g. Fabries et al., 1991, 1998; Lagabrielle and 137 Bodinier, 2008; Jammes et al., 2009; Clerc et al., 2012, 2013; Masini et al., 2014; Tugend et 138 al., 2014; Lagabrielle et al., 2016). It is commonly accepted that hyperextension and mantle 139 exhumation are responsible for a high-temperature and low-pressure (HT/LP) metamorphism 140 (Ravier, 1959; Bernus-Maury, 1984; Azambre and Rossy, 1976; Golberg and Leyreloup, 1990; 141 Dauteuil and Ricou, 1989; Clerc and Lagabrielle, 2014; Clerc et al., 2015; Ducoux, 2017; 142 Ducoux et al., 2019). This HT/LP metamorphic event affecting the southern NPZ it is mainly 143 evidenced by marbles of the IMZ issued from pre-rift to syn-rift sediments, with peak 144 conditions up to $600^{\circ} \mathrm{C}$ and below 4kbar (Bernus-Maury, 1984; Golberg and Leyreloup, 1990; 145 Vauchez et al., 2013; Clerc et al., 2015). Available $T_{\max }$, obtained with the Raman Spectroscopy 146 of Carbonaceous Materials (RSCM) method along the IMZ, first suggested the existence of a 147 temperature gradient from west to east (Clerc et al. 2015), but more recent studies of the 148 westernmost orogen (i.e. Basque-Cantabrian Basin) showed otherwise with equally high This article is protected by copyright. All rights reserved. 
149 maximum temperatures in the east and west (Ducoux et al., 2019). Published geochronological

150 data indicate ages ranging from Albian to Santonian (110-85 Ma) for this HT/LP metamorphic

151 event, demonstrating a short delay (10 My) between the end of rifting event (Cenomanian) and

152 the end of the HT/LP metamorphism (Santonian) (Albarède and Michard-Vitrac, 1978a;

153 Albarède and Michard-Vitrac, 1978b; Montigny et al., 1986; Golberg and Maluski, 1988;

154 Golberg et al., 1986; Bandet and Gourinard in Thiébaut et al., 1988; Clerc et al., 2015; Chelalou

155 et al., 2016).

156 The end of rifting was rapidly followed by the onset of convergence across the Pyrenean belt

157 during the Late Santonian, as suggested by tectonic and sedimentological data (Garrido-Megias

158 \& Rios 1972; Muñoz, 1992; Vergés et al., 1995; Teixell, 1998; Vergés \& García-Senz, 2001;

159 García-Senz 2002; McClay et al., 2004; Biteau et al., 2006; Mouthereau et al., 2014). After a

160 quiet tectonic period during the Paleocene (Danian to early Selandian, Ford et al., 2016), the

161 main collisional phase occurred in Eocene-Oligocene times (Muñoz 1992, 2002; Vergès et al.

162 2002; Mouthereau et al., 2014), ultimately leading to the present-day structure. The collisional

163 phase ended during the Chattian in the NPZ (Ortiz et al., 2020) but remained active in the

164 southern Pyrenees until the early Miocene (Muñoz et al., 1992; Hogan and Burbank, 1996;

165 Teixell, 1996; Millán Garrido et al., 2000; Millán Garrido, 2006; Jolivet et al., 2007; Oliva-

166 Urcia et al., 2015; Labaume et al., 2016). Finally, after the main collisional event, since the

167 middle Oligocene, the Eastern Pyrenees were affected by extensional deformation associated 168 with the opening of the Valencia Trough and Gulf of Lion (e.g. Gorini et al., 1993; Gorini et

169 al., 1994; Mauffret et al., 1995; 2001; Roca et al., 1999; Vergés and Garcia-Senz, 2001; Roca,

170 2001; Wehr et al., 2018; Etheve et al., 2018; Jolivet et al., 2020). 
173 The architecture of the eastern NPZ consists of the Agly Massif, the easternmost North

174 Pyrenean massif (Fig. 1), bounded by the Boucheville Basin to the south and the St-Paul-de-

175 Fenouillet and Bas-Agly synclines to the north (Fig. 2). The Agly massif, which represents a

176 condensed crustal section, is composed of plutonic and metamorphic rocks affected by a

177 Variscan HT/LP metamorphism (granulite to greenschist facies) (Barnolas et al., 1996; Guille

178 et al., 2018; Olivier et al., 2008; Wickham \& Oxburgh, 1986). This metamorphic event is

179 characterized by a strong geothermal gradient, locally higher than $100^{\circ} \mathrm{C} / \mathrm{km}$ (Fonteilles 1976 ;

180 Vielzeuf 1984; Delay 1990, Berger et al., 1993). The upper parts of the massif are composed

181 by thick Ediacarian to Devonian metasediments and by granitoids (Fonteilles, 1970; Berger et

182 al., 1993; Casas and Palacios, 2012). The deepest parts contain thin sheets of paragneisses and

183 orthogneisses derived from granitic sills emplaced at ca. 540 Ma (Guille et al., 2019).

184 Deformation and late Variscan HT/LP metamorphism that affect these para and ortho-derived

185 series have been variably interpreted as distributed mylonitic shear zones during the Variscan

186 orogeny between 305 and 296 Ma (e.g Olivier et al., 2004, 2008; Wickham \& Oxburgh, 1986;

187 Vanardois et al., 2020) or during a late Variscan extensional event related to a major detachment

188 fault in the middle crust (Bouhalier et al., 1991). Part of this high-strain mylonitic deformation

189 has alternatively been attributed to the Cretaceous rifting event (Passchier, 1984; Costa and

190 Maluski, 1988; St Blanquat et al., 1990; Delay, 1990; Delay \& Paquet, 1989; Paquet and

191 Mansy, 1991; Vauchez et al., 2013; Clerc et al., 2016; Odlum and Stockli, 2019). Low-grade

192 Ordovician to Devonian metasediments (mainly metapelites, shales and carbonates) compose

193 the northeastern part of the Agly massif. They were weakly metamorphosed in the chlorite zone

194 of the regional HT/LP metamorphism (Berger et al., 1993), while high-grade gneissic and

195 granulitic rocks are observed in the southwestern domain (Fig. 2). The Agly basement was also

196 affected by hydrothermal alteration during the rifting episode, as revealed by $98 \pm 2 \mathrm{Ma}$

197 albitization within the St. Arnac pluton (Poujol et al., 2010). This massif is finally crosscut by

This article is protected by copyright. All rights reserved. 
198 numerous $\mathrm{N} 110^{\circ}$ E-striking faults displaying down-dip slickenlines attributed to Pyrenean

199 collision (Olivier et al., 2004).

200 The Mesozoic sedimentary sequence of the area is exposed in the St-Paul-de-Fenouillet and 201 Bas-Agly synclines, and in the Boucheville basin. It starts with unconformable continental 202 Permian to Middle Triassic deposits, only observed in the southern margin of the Mouthoumet 203 massif. These sediments are missing over the Agly massif and the northern margin of the Axial 204 Zone (Fig. 2). Shallow marine Upper Triassic sediments are carbonates, clays and evaporites 205 (Keuper facies) passing upward to Liassic to late Aptian shallow marine limestones. The Albian 206 period is then marked by the opening of the large and interconnected basins Albian to 207 Cenomanian "Flysch Noir" basin (Debroas \& Souquet 1976; Debroas, 1990; Berger et al., 208 1997), later dismembered during convergence and now preserved in the St-Paul-de-Fenouillet, 209 Boucheville and Bas-Agly synclines (Fig. 2). Post-rift late Cenomanian-Turonian flysch 210 deposits are transgressive on underlying older syn-rift sequences (Debroas 1990; Debroas in 211 Ternet et al., 1997), and were continuously deposited until the early-Coniacian, onlapping the 212 northern part of Axial Zone and the North Pyrenean massifs (Debroas, 1987; 1990). The 213 Pyrenean convergence was responsible for the positive inversion of the rifted basins from the 214 Santonian to the Eocene (Bessière et al., 1989). From Miocene to Present, the eastern part of 215 the Pyrenean range was characterized by the development of extensional structures due to the 216 opening of the Gulf of Lion (Berger et al., 1993).

217 The Boucheville unit is a large synclinorium (Choukroune, 1970, Chelalou et al., 2016) 218 showing evidence of early extensional ductile deformation coeval with the rifting event 219 (Chelalou et al., 2016). The Boucheville syncline and the eastern part of the Agly massif are 220 separated from the Axial Zone by the sub-vertical North Pyrenean Fault (Fig. 2). To the 221 northeast of the Agly massif, the Bas-Agly syncline overthrusts the eastern part of the St-Paul222 de-Fenouillet syncline (Fig. 2) that is limited, to the north, by the south-dipping NPFT (Fig. 2). This article is protected by copyright. All rights reserved. 
223 The northern border of the Agly massif, corresponding to the southern Bas-Agly syncline,

224 shows the remains of a décollement of the pre-rift cover (Durand-Delga, 1964; Légier et al.,

225 1987; Clerc and Lagabrielle, 2014; Clerc et al., 2016) with tectonic lineations and drag folds

226 indicating a top to the NNE displacement (Légier et al., 1987; Vauchez et al., 2013). The Bas-

227 Agly/St-Paul-de-Fenouillet and the Boucheville synclines are interpreted in most restorations, 228 as two separate rifted basins on either side of the Agly massif, the latter corresponding to a 229 tilted basement block (Vauchez et al., 2013; Clerc et al., 2015; 2016; Ternois et al., 2019; 230 Odlum and Stockli, 2019). In these rift restorations, the Boucheville syncline sits on the rift axis 231 above exhumed lithospheric mantle, while the Bas-Agly and St-Paul-de-Fenouillet synclines 232 sit on hyperthinned to thinned continental crust.

\section{Materials and Methods}

To determine the distribution of the HT/LP metamorphism and then compare with the

235 deformation pattern, we sampled 9 Mesozoic rocks of the Bas-Agly and the St-Paul-de236 Fenouillet synclines for determining the maximum recorded temperatures with the RSCM 237 method (Beyssac et al. 2002a; Lafhid et al. 2010). This data set completes the previous works 238 focused on the HT/LP metamorphism (Clerc et al., 2015; Chelalou, 2015). This analytical 239 method allows characterizing the structural evolution of carbonaceous material (CM), reflecting 240 a transformation from disordered to well-ordered CM during metamorphism (Wopenka and 241 Pasteris, 1993). The relation of this increasing graphitization with temperature was quantified, 242 leading to a tool to determine peak temperatures attained by metamorphic rocks (Beyssac et al., 243 2002a). Since graphitization is an irreversible process, the RSCM method gives the temperature 244 peak (Pasteris and Wopenka, 1991; Beyssac et al., 2002a). This is the basis of the RSCM 245 geothermometer, which was calibrated in the range between 330 and $650^{\circ} \mathrm{C}$ by Beyssac et al. 246 (2002a) and extended to the range between 200 and $320^{\circ} \mathrm{C}$ by Lahfid et al. (2010). In this study, 247 we applied these two calibrations to estimate paleotemperatures in carbonates and pelitic

This article is protected by copyright. All rights reserved. 
248 metasedimentary rocks from the Paleozoic and Upper Cretaceous series of the study area.

249 Raman analysis protocol is described in supplementary material. The entire results are

250 presented in Table SM1 in supplementary materials and Figures 2 and 3 ( $T_{\max }$ values of this 251 study are display in red) with the details of the data acquisition protocol.

\section{Thermal pattern of the eastern NPZ}

4.1. Distribution of the HT/LP metamorphism

254 The eastern part of NPZ has been extensively studied and numerous studies propose 255 temperature estimates for the HT/LP Pyrenean metamorphic event with different methods 256 including the RSCM approach (e.g Golberg, 1987; Golberg and Leyreloup, 1990; Clerc et al., 257 2015; Chelalou, 2015; Chelalou et al., 2016). The Boucheville syncline is largely affected by 258 this HT/LP metamorphism and has recorded rather homogeneous peak temperatures comprised 259 between 530 and $580^{\circ} \mathrm{C}$ (Golberg et Leyreloup, 1990; Chelalou et al., 2016) (Figs. 2 and 3). 260 Locally, near the southern edge of the basin, within pre-rift Jurassic sediments, $T_{\max }$ are below $261500^{\circ} \mathrm{C}$ (Chelalou et al., 2016). According to Clerc et al. (2015), the eastern part of the Agly 262 massif, made of Ordovician to Devonian metasediments, experienced $T_{\max } 351 \pm 3^{\circ} \mathrm{C}$ measured 263 in Silurian metasediments and close to the contact with the south margin of the Bas-Agly 264 syncline (Fig. 2). Our data confirm this trend, with a $T_{\max }$ of $351 \pm 12^{\circ} \mathrm{C}$ measured a few 265 kilometers westward. This range of $T_{\max }$ shows that the thermal event has not affected or has 266 not exceeded $350^{\circ} \mathrm{C}$ in the upper part of the Agly massif.

267 Remnants of the metamorphic Mesozoic cover lying on the central-western part of Agly basement (Berger et al., 1993; Fonteilles et al., 1993), more precisely in the Serres de Verges area, correspond to Jurassic and Lower Cretaceous brecciated metasediments. We measured in this unit a $T_{\max }$ of $424 \pm 32^{\circ} \mathrm{C}$ obtained in foliated clasts (Fig. 2). This value of $T_{\max }$ shows highgrade metamorphic conditions of the Mesozoic sedimentary cover, located above high-grade

This article is protected by copyright. All rights reserved. 
272 Variscan metamorphic rocks of the Agly massif. Thus, there is no observed metamorphic gap

273 between the breccia and the basement. Measured $T_{\max }$ in the Mesozoic metasediments of the

274 eastern Agly massif are instead higher than in Paleozoic rocks, the latter being only affected by

275 low-grade metamorphism under low greenschist-facies conditions.

276 We measured $T_{\max }$ higher than $550^{\circ} \mathrm{C}$ in the Cretaceous core of the Bas-Agly syncline. The 277 highest $T_{\max }$ estimated in this syncline correspond to respectively $570 \pm 27^{\circ} \mathrm{C}$ and $566 \pm 15^{\circ} \mathrm{C}$ 278 in Valanginian and Aptian metacarbonates. A $T_{\max }$ of $534 \pm 19^{\circ} \mathrm{C}$ is recorded in black Albian 279 marbles in the central part of the syncline (Fig. 2). In a previous study (Chelalou, 2015), a 280 similar range of $T_{\max }$ comprise between 530 to $559^{\circ} \mathrm{C}$ was characterized. In the southern Bas281 Agly syncline, close to the contact with the Agly massif and documented by previous studies, $282 T_{\max }$ decreases around $350^{\circ} \mathrm{C}$ with a local value of $494^{\circ} \mathrm{C} \pm 7^{\circ} \mathrm{C}$ in anhydrite-rich Upper Triassic 283 sediments (Clerc et al., 2015). Intermediate temperatures comprised between 450 and $400^{\circ} \mathrm{C}$ 284 (Golberg and Leyreloup, 1990) indicate a progressive southward decrease of metamorphic 285 grade (Fig. 2). In the Bas-Agly, the highest temperatures are thus recorded in the central part of 286 the syncline.

287 In the Albian marls of the St-Paul-de-Fenouillet syncline, we measured a local $T_{\max }$ value of $288246^{\circ} \mathrm{C}$ and two $T_{\max }$ lower than $200^{\circ} \mathrm{C}$. These temperatures corresponding to low-grade 289 metamorphism, are in agreement with previous data obtained in this syncline, which are 290 comprised between 200 and $290^{\circ} \mathrm{C}$ (Chelalou et al., 2016). In the eastern part of this basin, 291 close to the contact with the Bas-Agly syncline, we also obtained $T_{\max }$ lower than $200^{\circ} \mathrm{C}$ (Fig. 292 2) confirming that the whole basin has not been heated, which marks a major difference with 293 both the Bas-Agly and Boucheville synclines. A map of Cretaceous HT/LP metamorphism distribution has been interpolated from the available $T_{\max }$ and field geological data in the eastern part of the ZNP (Fig. 3). It shows a clear 
thermal contrast between the Boucheville and the Bas-Agly synclines on the one hand, and the

297 St-Paul-de-Fenouillet syncline on the other hand. Both the Bas-Agly and Boucheville synclines

298 show lateral temperature gradients within the sediments that cannot be attributed to differential

299 burial. Actually, the highest temperatures are observed in the syn-rift sediments, while pre-rift

300 sediments experienced only moderate temperatures $\left(\sim 400^{\circ} \mathrm{C}\right.$ for the Boucheville syncline and 301 between 350 and $400^{\circ} \mathrm{C}$ for Bas-Agly syncline) (Fig. 3). Consequently, HT/LP metamorphic

302 isograds are oblique on the bedding in those basins and on different structures observed in this

303 area. A thermal gap $\left(>250^{\circ} \mathrm{C}\right)$ is observed across the Tautavel thrust fault bounding the Bas304 Agly and St-Paul-de-Fenouillet synclines, connecting northward with the NPFT (Figs. 2 and $3053)$.

306 To summarize the distribution of the thermal imprint of the Cretaceous HT/LP metamorphism, 307 the Boucheville and Bas-Agly synclines show the highest grade of metamorphism with $T_{\max }$ 308 exceeding $500^{\circ} \mathrm{C}$. The underlying eastern Agly massif experienced $T_{\max }$ never exceeding $309350^{\circ} \mathrm{C}$, a peak-temperature colder than these two metamorphic Mesozoic synclines. 310 Furthermore, this contrast of $T_{\max }$ between basement and metamorphic Mesozoic sedimentary 311 cover is attested by remnants of Mesozoic sediments located above the Agly massif, where $T_{\max }$ 312 exceeds $400^{\circ} \mathrm{C}$. Thermal contrast is most significant between the Boucheville/Bas-Agly313 synclines and the St-Paul-de-Fenouillet syncline where $T_{\max }$ does not exceed $250^{\circ} \mathrm{C}$.

315 Below the basal contact of the Bas-Agly syncline, the north-eastern margin of the Agly massif 316 is made of low metamorphic grade sediments (Fig. 4). Silurian sandstones and feldspathic 317 shales that composed the Paleozoic basement of the northeastern Agly massif still show 318 graptolites and preserved turbiditic sedimentary figures. This upper part of the basement is only 319 affected by a series of $\mathrm{N} 110^{\circ} \mathrm{E}$ localized metric-scale shear bands (Fig. 5), some of which 320 corresponding to N-verging normal faults (Fig. 5a). We also observe reverse faults with a top- 
321 to-the S sense of shear, suggested by folding and reverse offset of sandstone layers (Fig. 5b).

322 The northeast Agly massif is thus affected by various brittle and brittle-ductile shears, but no

323 pervasive ductile deformation is observed (Fig. 5), in agreement with the measured low $T_{\max }$.

324 Our observations are in agreement with previous studies (Légier et al., 1987; Vauchez et al.,

325 2013). Only the contact between low-grade metasediments and high-grade metamorphic rocks

326 underneath are associated with ductile deformation previously attributed to the Variscan event

327 (Berger et al., 1933 and references therein).

328 In contrast with the Paleozoic low-grade metasediments of the Agly Massif affected by brittle

329 deformation, the Rhaetian and Liassic sediments of the Bas-Agly syncline show an intense 330 ductile deformation with stretching lineation and plurimetric-scale boudinage (Figs. 4 and 6),

331 with a NNE-ward sense of shear (Vauchez et al., 2013). The base of this sedimentary cover is

332 associated to the development of north-verging recumbent metric folds as well (Fig. 6a and b).

333 It is worth noting the presence of Upper Triassic evaporites at the base of the sedimentary pile.

334 The contrasted deformation observed in the different units confirmed the distribution of $T_{\max }$

335 with higher temperature in the cover than in the basement.

336 As for the Bas-Agly, this ductile deformation is also observed in the Boucheville syncline

337 equally affected by the HT/LP metamorphism. This syncline is strongly overprinted by 338 Pyrenean-related compressional deformation responsible for the development of N110 339 striking cleavage (Fig. 4). This cleavage is coeval with the development of the main faults (as 340 the North Pyrenean Fault) which bound the Boucheville syncline, attributed to the late 341 convergence (Berger et al., 1993). Concerning the Bas-Agly syncline, only its southern margin 342 is folded and associated to the late subvertical cleavage. This deformation zone is located along 343 the extension of the Latour-de-France Fault, responsible of the late thrusting of the Agly massif 344 over the Bas-Agly. This cleavage is not clearly expressed in the rest of the Bas-Agly syncline. 345 However, this subvertical cleavage extends into the St-Paul-de-Fenouillet syncline until the This article is protected by copyright. All rights reserved. 
346 NPFT (Fig. 4). No cleavage is observed to the north of the North Pyrenean Frontal Thrust. Only

347 salt tectonics-related structure is preserved (Fig. 4).

348 The contact between the Mesozoic sediments and the crystalline/metamorphic basement 349 (orange faults in Fig. 4) is mainly observed in the eastern Boucheville syncline and along the 350 southern margin of the Bas-Agly syncline. This flat-lying contact is characterized by the 351 presence of breccia recognized on the top of the Agly Massif and at the base of Jurassic series 352 in the Bas-Agly. Furthermore, the surface of this contact is subsequently deformed and 353 truncated by a fault (Durand-Delga, 1964). The contact between the Bas-Agly and the St-Paul354 de-Fenouillet corresponds to the Tautavel fault which consist to a low angle thrust connected 355 to the NPFT (Fig. 4).

356 The Boucheville and Bas-Agly syncline are always limited by tectonic contacts with the 357 basement. On the opposite, the St-Paul-de-Fenouillet syncline is lying over the northern margin 358 of the Agly massif without any significant deformation (Fig. 4), suggesting that it could be the

359 autochthonous Mesozoic sedimentary cover of the Agly massif.

\section{Discussion and interpretation: tectonic consequences of the IMZ thermal} structure

\subsection{Architecture of the eastern North Pyrenean Zone}

363 The geological cross-sections of figure 7 show the structure of the eastern part of the IMZ and 364 its relationships with NPZ and the Agly massif (Fig. 7). The Boucheville Basin corresponds to 365 an asymmetric synclinorium (e.g. Choukroune, 1976; Chelalou et al., 2016) bounded by two 366 steeply-dipping major faults, including the North Pyrenean Fault to the south. These faults 367 affect both the basement and the IMZ (Figs. 4 and 7a) and can be extended eastward within the

368 Agly massif where they offset Variscan metamorphic isograds (Fig. 7a). These steeply-dipping 369 faults are intersected by late normal faults linked to the formation of grabens filled by Miocene-

This article is protected by copyright. All rights reserved. 
370 Quaternary sediments (Figs. 4 and 7b). Variscan structures within the Agly massif have been

371 deformed during the Pyrenean compression, and are affected by WNW-ESE striking reverse

372 faults (Olivier et al., 2004).

373 West of Latour-de-France, the contact between the Bas-Agly syncline and the Agly massif is 374 overturned and faulted (Latour-de-France Fault) while, further east, the Bas-Agly cover is flat375 lying on the top of Paleozoic series with a tectonic contact (Figs. 2 and 4). The northern limb 376 of the Bas-Agly syncline overthrusts the St-Paul-de-Fenouillet syncline through the Tautavel 377 Fault that extends and connects with the NPFT further north (Fig. 4). West of Maury, the low378 temperature Mesozoic sequence of the St-Paul-de-Fenouillet syncline, which is the cover of the 379 Paleozoic basement of the Agly massif, is still present, only partly detached thanks to the 380 Triassic evaporites.

381 Isograds of metamorphism are represented on the geological cross sections and show the 382 distribution of HT/LP Cretaceous metamorphism in the eastern NPZ (Fig. 7). In the Boucheville 383 Basin, temperature isograds are clearly intersected by steeply-dipping faults that bound the 384 basin (Fig. 7a). Moreover, a large gap of temperature across the Tautavel Fault is evidenced on 385 both cross sections (Fig. 7). Folding observed in the Mesozoic sedimentary cover results partly 386 from the late compressional event, but some folds may result from the halokinesis active during 387 the rifting event. Temperature isograds are overturned, intersected and shifted by late 388 deformational structures and faults. However, the distribution of metamorphism in these 389 synclines is rather heterogenous and shows lateral temperature gradients within the basin. 390 Isograds in the Bas-Agly syncline clearly intersect bedding. This observation was already made 391 in the Western Pyrenees, especially in the Basque-Cantabrian Basin and in the Chaînons 392 Béarnais area, where the obliquity of isotherms on the structure is due to a pre-metamorphic 393 folding related to salt tectonics (Ducoux et al. 2019; Izquierdo-Llavall et al., 2020).

This article is protected by copyright. All rights reserved. 
5.2. Significance of temperature and deformation contrasts across tectonic contacts.

395 The central parts of the Bas-Agly and Boucheville synclines show significantly higher 396 temperature $>450^{\circ} \mathrm{C}$, while the St-Paul-de-Fenouillet syncline shows temperatures $<250^{\circ} \mathrm{C}$. 397 The temperature gap between the Bas-Agly and St-Paul-de-Fenouillet synclines is abrupt and 398 corresponds to the Tautavel thrust fault. On the other hand, the metamorphic contrast is 399 significant between Paleozoic shales with low-grade greenschist facies conditions (HT/LP 400 Variscan metamorphism) of the northern Agly massif and Mesozoic sediments with higher $401 T_{\max }$. Consequently, the Bas-Agly and Boucheville synclines were affected by Cretaceous HT402 metamorphism, coeval with mantle exhumation, but not the overlying northern Agly massif 403 which never experienced temperature exceeding $350^{\circ} \mathrm{C} . T_{\max }$ measured in the Paleozoic 404 metasediments of the northern Agly massif can either date back to the Paleozoic or to the 405 Cretaceous rifting event, but the measured temperature shows that the basement has seen lower 406 temperatures than the overlying cover. Note that we do not discuss here the southern part of the 407 Agly massif where the HT/LP metamorphism has been attributed to the Variscan event 408 (Vielzeuf and Kornprobst, 1984) or to the Cretaceous HT/LP episode (Odlum and Stockli, 409 2019). It is commonly admitted that the regional HT/LP that affects the NPZ is coeval with the 410 Lower Cretaceous crustal thinning event (Ravier, 1959; Bernus-Maury, 1984; Azambre and 411 Rossy, 1976; Golberg and Leyreloup, 1990; Dauteuil and Ricou, 1989; Clerc and Lagabrielle, 412 2014; Clerc et al., 2015). In the Boucheville synclinorium, the paleogeothermal gradient during 413 this $\mathrm{HT} / \mathrm{L} P$ metamorphic event has been estimated between 70 and $80^{\circ} \mathrm{C} / \mathrm{km}$ (Chelalou et al., 414 2016). Recent low-temperature thermochronological study indicates that the Agly block cooled 415 below $250^{\circ} \mathrm{C}$ during the syn- to post rifting (117-90 Ma) (Odlum \& Stockli, 2019; Ternois et 416 al., 2019), indicating significant lower temperatures than bounding metamorphic sedimentary 417 basins that recorded temperatures $>500^{\circ} \mathrm{C}$ during the post-rift period (95-90 Ma) (Clerc et al.,

This article is protected by copyright. All rights reserved. 
418 2015). Thus, the HT/LP metamorphism during the Cretaceous would have been confined to

419 the southern Agly massif, like further west in the Aulus Basin for instance.

420 With reference to the distribution of HT-metamorphism, the deformation in the different units 421 is also contrasted. Intense ductile deformation is observed in the Bas-Agly and Boucheville 422 synclines that recorded the highest temperatures, while the underlying Silurian strata 423 corresponding to Paleozoic cover of the Agly Massif, where temperature are lower, are much

424 less deformed and certainly not mylonitized. Remnants of a Mesozoic cover are locally 425 preserved on top of the Agly Massif, such as cataclastic breccias containing clasts of HT 426 ductilely deformed marbles sealed by unmetamorphic cement. These observations and the 427 temperature higher than $400^{\circ} \mathrm{C}$ in marble clasts in the Serre de Vergés area confirm that the 428 breccia is a post-metamorphic event.

429 In previous studies, the contact between the Agly massif and the Bas-Agly syncline has been 430 interpreted as the result of basal truncation of a detached Mesozoic cover (Durand-Delga, 1964;

431 Légier et al., 1987) and recently reinterpreted as a north-dipping extensional detachment, the 432 Agly massif being in the position of a metamorphic core complex (Vauchez et al., 2013; Clerc 433 and Lagabrielle, 2014) where extensional deformation near the contact in the Mesozoic cover 434 would be expressed by the boudinage and drag folds (Clerc et al., 2016). In this interpretation, 435 the Bas-Agly syncline corresponds to the detached sedimentary cover of the Agly massif, 436 decoupled via a décollement layer in Upper Triassic sediments (Vauchez et al., 2013; Clerc et 437 al., 2016). EBSD and field study in carbonate layers of the base of the Bas-Agly syncline 438 suggest that this $\mathrm{N}$ - to NE trending ductile shearing was developed at a temperature around $439400^{\circ} \mathrm{C}$ (Vauchez et al., 2013). In the opposite way, a recent study suggests that the Lower 440 Cretaceous exhumation of the southern part of the Agly massif by extension was accommodated 441 by a top-to-the south detachment (Odlum \& Stockli, 2019).

This article is protected by copyright. All rights reserved. 
442 The extensional model and the pre-orogenic restorations of Vauchez et al (2013), Clerc et al.

443 (2016) and more recently the crustal-scale model of Ternois et al. (2019) and Odlum \& Stockli

444 (2019) do not easily explain the thermal imprint measured in the central part of the Bas-Agly

445 syncline. In particular they do not explain the higher $T_{\max }$ measured in the Bas-Agly syncline.

446 Figure 8 shows two typical situations of a metamorphic core complex and a thrust in terms of

447 deformation and thermal structure. First of all the contrast in $T_{\max }$ is the opposite in the two

448 situations. A detachment with a significant displacement will inevitably lead to cold 449 (superficial) over hot (deep) units, while a thrust will show the opposite arrangement (Fig. 8a).

450 Then, all detachments show a continuum of ductile-to-brittle deformation within a distinct shear

451 zone that is mostly observed in the lower plate, below the detachment (Crittenden et al., 1980;

452 Davis and Lister, 1988) and the lower plate display more ductile deformation while the upper

453 plate shows mostly brittle deformation, which is the exact opposite to what is observed in the

454 study area. The deformation observed in the Paleozoic sediments of the top of the Agly massif

455 is weak and certainly does not correspond to a major shear zone.

456 Then the question arises about the significance of the observed ductile deformation at the base

457 of the Bas-Agly syncline. The N-NE trend of stretching lineations and calcite fabrics near the 458 base of the Bas-Agly syncline described by Vauchez et al. (2013) attests for a northward 459 displacement of the metamorphic unit corresponding to the current Bas-Agly syncline, but it 460 does not prove that it corresponds to an extensional deformation. Here, the large thermal 461 contrast between the hot metamorphic Mesozoic cover and the colder Paleozoic basement 462 underneath is opposite and thus more compatible with a thrust than a detachment (Fig. 8b).

463 Finally, models proposed by Vauchez et al (2013), Clerc et al. (2016), Ternois et al. (2019) and 464 Odlum \& Stockli (2019) describe the Boucheville and Bas-Agly synclines as two narrow 465 disconnected basins on either side of the Agly basement massif, but this assumption conflicts 466 with sedimentological observations indicating that Aptian, Albian and Lower Cretaceous This article is protected by copyright. All rights reserved. 
467 pelagic sediments (corresponding to "Flysch noirs") were likely deposited in a unique large

468 basin and not in two narrow separated basins (Olivier, 2013).

469 The main question then concerns the link between the Mesozoic sedimentary cover and 470 Paleozoic rocks of the Agly massif. A section along the northern margin of the Agly massif 471 further west, near Maury, shows that the St-Paul-de-Fenouillet syncline is the poorly 472 metamorphosed Mesozoic cover of the Agly Paleozoic basement, in agreement with the low 473 temperatures observed in the St-Paul-de-Fenouillet Basin. When moving east, this sedimentary 474 cover is substituted by the Bas-Agly syncline that is more intensely metamorphosed and the 475 contact between the St-Paul-de-Fenouillet syncline and the Bas-Agly corresponds to a well476 characterized thrust that connects to the north with the North Pyrenean Frontal thrust. Then, 477 two hypotheses can be proposed: (1) the Bas-Agly syncline may be the eastern equivalent of 478 the St-Paul-de-Fenouillet Basin with a higher metamorphic grade and the two basins were 479 carried along the basal decollement in Upper Triassic evaporites until they got into close 480 contact; (2) alternatively, the Bas-Agly syncline may be the western termination of a rift 481 segment developing eastward, if we consider the eastern termination of Pyrenees as a relay or 482 accommodation zone where the rift axes are shifted. The Boucheville and Bas-Agly synclines 483 may corresponded to V-shaped terminations of two rifted basins, as the western Pyrenees for 484 instance (e.g. Lescoutre \& Manatschal, 2020); (3) the Bas-Agly syncline is not the cover of the 485 Agly massif and corresponds instead to a displaced outlier of a more internal and hotter unit 486 where high temperature is due to mantle exhumation as elsewhere in the NPZ.

487 By combining structural observations and new $T_{\max }$ dataset we then propose an alternative 488 interpretation whereby the Bas-Agly syncline corresponds to a northern klippe of the 489 Boucheville Basin thrusted over the Agly massif and a part of St-Paul-de-Fenouillet during the 490 Pyrenean shortening. In this interpretation, the Bas-Agly would connect above the Agly massif 491 with the more internal Boucheville syncline, where high temperatures are recorded.

This article is protected by copyright. All rights reserved. 
492 The top-north detachment described by Vauchez et al. (2013) in the northeastern part of the

493 Agly Massif in then reinterpreted as a top-to-the north thrust instead, assisted by regional-scale

494 well known Upper Triassic evaporites layer. This interpretation explains the distribution of 495 metamorphism, the observed temperature contrasts recorded within the different synclines and 496 the distribution of deformation.

\subsection{A 2D crustal-scale geodynamic model}

498 Figure 9 presents a basin-scale restoration model showing a possible evolution of the eastern

499 end of the NPZ from the rifting stage to the end of the Pyrenean orogeny. Based on the model

500 of Ternois et al. (2019) for the crustal architecture, we propose a different interpretation for the 501 sedimentary cover, in which the Bas-Agly syncline represents an allochthonous unit initially 502 connected with the Boucheville syncline above a body of exhumed mantle during the

503 Cretaceous rifting, where both formed a single basin and then transported northward by a thrust.

504 The first step represents the rift template before the onset of the convergence during the

505 Santonian with the inversion of the hyperextended rifted margins formed a span of 30 Myrs 506 between early Aptian to early Cenomanian stages (Fig. 9a). Rifting was associated to 507 hyperthinning of the lithosphere accommodated by the development of a large-scale top-to-the508 south detachment fault located at the base of the basin which induced mantle exhumation and 509 HT/LP metamorphism in the pre- and syn-rift sediments. Such model of crustal boudinage was 510 already proposed by Clerc et al. (2016), but we show here that the northern side of the Agly 511 massif was not affected by ductile deformation during rifting. On the opposite, the Cretaceous 512 basin was affected by intense ductile deformation during this episode, especially in the northern 513 part of the Boucheville Basin (Chelalou et al., 2016). The syn-rift geometry supposes that the 514 Boucheville, Bas-Agly and St-Paul-de-Fenouillet basins are connected and are filled mainly by 515 Albian-Cenomanian deposits. The Agly massif represents a paleo-topographic high, but it was 516 never significantly eroded before the Late Cretaceous, because there is no evidence of Paleozoic This article is protected by copyright. All rights reserved. 
517 clasts in Aptian to Cenomanian deposits (Olivier et al., 2013). It is only covered by a thin

518 succession of syn-rift sediment (Fig. 9a). We suggest that the Agly massif separates two basins

519 probably interconnected laterally farther west and probably farther east. There is no argument

520 to bury the Agly paleo-high beneath a thick pile of syn-rift sediments. On the contrary, there is

521 a possibility that this paleo-high was only buried beneath post-rift successions. This assumption

522 is supported by recent thermochronological data (Odlum \& Stockli, 2019; Ternois et al., 2019).

523 The eastern NPZ consist in rift and salt architecture with salt pillows, diapirs and raft of the

524 syn-rift sediment further north, driven by gravity gliding of the Mesozoic cover. In this model,

525 syn-rift sediments were deposited over the pre-rift sediments that experienced gravity gliding

526 and were juxtaposed above exhumed mantle and a thin continental crust corresponding to the

527 future Boucheville and Bas-Agly basins where HT/LP metamorphism developed (Fig. 9a). We

528 assume a juxtaposition of pre- and syn-rift sediments and exhumed mantle; but we cannot

529 exclude the possibility that the Mesozoic basin was sitting on a very thin continental crust and

530 not directly on the exhumed mantle, because there is no evidence of mantle clast and/or

531 volcanism in this area. During the onset of convergence, the hyperextended domain is firstly

532 reactivated and inverted up to collision of both margins Gómez-Romeu et al. (2019).

533 The second step corresponds to the Late Cretaceous convergence with the inversion of the two

534 hyper-extended margins after underthrusting of the exhumed mantle and reactivation of the

535 necking domain associated to the development of the south-verging thrusts located in the Axial

536 Zone and the NPFT (Fig. 9b). A major thin-skinned flat-lying thrust rooted in the Upper Triassic

537 decollement level allowed the northward displacement of the metamorphic part of the basin on

538 top of the St-Paul-de-Fenouillet Basin that recorded only low-grade metamorphism. We

539 hypothesize that the inherited detachment at the base of the basin associated to the decollement

540 layer has been reactivated as a thrust. Early salt pillows and diapirs could be responsible for the

541 localization of the major thin-skinned thrust, corresponding to the current Tautavel fault. In

This article is protected by copyright. All rights reserved. 
542 addition, this thrust is probably responsible for the development of breccias at the base of the

543 pre-rift cover. Indeed, these breccias may be a witness of the decollement level localized

544 between the basement and the Mesozoic sedimentary cover (Clerc et al., 2016). It is more 545 difficult to estimate the amount and the direction of this general displacement. The displacement 546 and the thermal contrast seem to decrease toward the east, and Bas-Agly syncline seems to be 547 interconnected with the St-Paul-de-Fenouillet syncline. It may be possible that the deformation 548 softened eastward, especially as this area corresponding to a well-known transfer zone 549 corresponding to the Corbières virgation (Tugend et al., 2014). In the rest of the Pyrenees, the 550 IMZ where higher $T_{\max }$ are recorded, is always interconnected with non-metamorphic basins to 551 the north where North Pyrenean massifs are missing or not outcropping (Clerc et al., 2015). 552 Recent study indicates that the thermal imprint of the metamorphism gently decreases when 553 moving away from the former distal part of the rift system (Ducoux et al., 2019).

554 The Paleocene corresponds to a period of tectonic quiescence, the convergence rate strongly 555 decreasing (Desegaulx and Brunet, 1990; Ford et al., 2016; Rougier et al., 2016; Machiavelli

556 et al., 2017; Grool et al., 2018; Dielforder et al., 2019; Ternois et al., 2019), as emphasized by 557 the absence of cooling at that age in the Agly blocks (Ternois et al., 2019) and by a minimal 558 deposition of clastic sediments in the Aquitaine retro-foreland basin (Desegaulx and Brunet, 559 1990, Ford et al., 2016). This tectonic quiescence could be attributed to the transition period

560 between the closure and inversion of both hyperextended domain and the beginning of crustal 561 thickening related to the collision strictly speaking.

562 The third step corresponds to the onset of the main collision phase and the beginning of crustal 563 thickening involving thick-skinned tectonic style and the development of crustal-scale thrust 564 faults in the pro-wedge domain (Ternois et al., 2019) (Fig. 9c). A major part of the deformation 565 is then accommodated within the basement by the reactivation of former normal faults in the 566 retro-wedge and by the neoformation of thrusts in the pro-wedge. The progressive crustal This article is protected by copyright. All rights reserved. 
567 thickening is responsible for basement exhumation, especially the Agly massif and sedimentary

568 cover as well (Fig. 9c). Recent thermochronological data indeed indicate a rapid exhumation of

569 the Agly massif near the surface during the Eocene, while the NPZ continues to shorten and 570 deformation migrates northward (Ternois et al., 2019). These recent data are in agreement with 571 other published thermochronological data which consistently suggest such a timing: $49 \pm 4$ to $57235 \pm 3 \mathrm{Ma}$ in Mauléon Basin (Western Pyrenees) (Vacherat et al., 2014); 50 to 35 Ma for North 573 Pyrenean massifs in the central Pyrenees (Vacherat et al., 2016); 44 to $35 \mathrm{Ma}$ in the Axial Zone 574 (Fitzgerald et al., 1999). In our model, the exhumation of the Agly block along the main thrust 575 caused a shift of the primary thrust (i.e. Tautavel fault, Figs. 2, 4 and 6), and a folding of the 576 Mesozoic cover that generated the current shape of the Bas-Agly syncline.

577 The last step corresponds to the end of collision with nappe stacking of the Axial Zone (Fig. $5789 \mathrm{~d})$. The shortening is mainly localized on the future SPFT at depth and on the NPFT. From the 579 middle Eocene to the early Oligocene, the Axial Zone records higher exhumation rates 580 (Whitchurch et al., 2011; Rushlow et al., 2013; Mouthereau et al., 2014; Bosch et al., 2016; 581 Labaume et al., 2016), while the exhumation of the Agly massif ceases (Gunnell et al., 2009; 582 Ternois et al., 2019). The NPZ is finally tilted and uplifted by the exhumation of the Axial Zone 583 related to crustal stacking. Consequently, the Boucheville and Bas-Agly synclines are now 584 separated by the Agly Massif (Fig. 9d). Only small remnants of sedimentary cover are observed 585 on the top of Agly massif. In this configuration, the North Pyrenean Fault corresponds to an 586 inherited structure related to the rifting event and was only reactivated as a reverse fault during 587 the end of collision. The main part of the deformation was accommodated by thick-skinned 588 deformation expressed by the stacking of basement nappes, corresponding to the present-day 589 Axial Zone. Thin-skinned deformation of the sedimentary cover was accommodated by the 590 Upper Triassic decoupling layer. Consequently, the distribution of the deformation is drastically 591 different between the basement and the sedimentary cover when an efficient decoupling layer This article is protected by copyright. All rights reserved. 
592 is present (e.g. Jammes et al., 2010; Jourdon et al., 2020). The presence of the Triassic evaporite

593 layer thus has considerably impacted the tectonic history of the eastern Pyrenees. First during

594 the rifting stage and then during the Pyrenean shortening.

595 After the main collision, the eastern Pyrenees was affected by normal faults associated with the 596 opening of Valencia Trough since the middle Oligocene (e.g. Roca et al., 1999; Roca, 2001;

597 Etheve et al., 2018; Jolivet et al., 2020).

599 Classical models describing the geodynamic evolution of the Pyrenean range do not address the 600 early convergence and the onset of the collision of the two hyper-extended margins. Before the 601 two last decades, the Pyrenean rift was described as a narrow rift and hyperextension and mantle 602 exhumation were thus not considered in geodynamic models (e.g Choukroune et al., 1990; 603 Munoz, 1992; Beaumont et al., 2000; Canérot, 2016). Some recent models suggested that the 604 distal part of the rift system, corresponding to deep basins sitting on the exhumed mantle, 605 formed an accretionary prism during the subsequent early inversion (e.g. Mouthereau et al., 606 2014; Ford et al., 2016). The early convergence setting is characterized by thin-skinned 607 tectonics in the sedimentary pile which corresponded to the former hyperextended domain 608 (mantle exhumation) (Fig. 9). A decollement propagates at the interface between Mesozoic 609 sediments and the basement (Paleozoic rocks and subcontinental mantle) within the Upper 610 Triassic evaporites. We further suggest that most of the distal rifted basin is transported over 611 the former necking domain along the former Cretaceous south-dipping detachment (Fig. 9). 612 This tectonic process is in agreement with recent studies promoting large displacements of 613 rifted basins along inherited decoupling layer (Gomez-Romeu et al., 2019; Labaume \& Teixell, 614 2020). Rift-related inheritances (crustal structures and rheology) may fundamentally control the 615 development and the finite structure of orogens by controlling the depth of the decoupling layer 616 and its propagation (e.g., Tugend et al., 2014; Lacombe \& Bellahsen, 2016; Gomez-Romeu et 
617 al., 2019; Tavani et al., 2020; Lescoutre \& Manatschal, 2020). Inversion of the hyperextended

618 domains depends of the depth of the efficient decoupling layer. The positioning of the

619 decoupling layer is variable and can be located at the interface between the basement and the 620 sedimentary units (e.g. Bellahsen et al., 2012; Muñoz et al., 2013; this study) or in the

621 serpentinized exhumed mantle which corresponds to the weakest part of rifted margins (Pérez-

622 Gussinyé et al., 2001; Péron-Pinvidic et al., 2008), where deformation may preferentially

623 initiate during the contractional deformation (Péron-Pinvidic et al., 2008; Lundin and Doré,

624 2011; Tugend et al., 2014 and 2015a; Gomez-Romeu et al., 2019). In the necking and proximal

625 domains, the continental crust is thicker, and the decoupling layer consequently develops in the

626 middle-lower crust (e.g.Pfiffner, 2017; Jourdon et al., 2019; Tavani et al., 2020). Therefore,

627 during contractional deformation thick-skinned tectonics is prevailing, and inherited rift-related

628 crustal structures may be reactivated (e.g. Froitzheim et al., 1988; Letouzey, 1990; Mitra et

629 Mount, 1998; Brown et al., 1999; Domènech et al., 2016) or intersected by syn-tectonic

630 structures (e.g. Bellahsen et al., 2012 ; Bellanger et al., 2014; Branellec et al., 2016). The

631 tectonic history of the eastern Pyrenees as discussed in this paper thus shows the succession of

632 two periods of the contractional deformation that led to the full inversion of the rifted margins.

633 Other sections, further west, except for the Basque-Cantabrian basin with the Nappe des

634 Marbres (Ducoux et al. 2019; Lescoutre and Manatschal, 2020), show a narrower IMZ where

635 most units are pinched and vertical, thus obliterating the details of the shortening history. The

636 Agly section and the Nappe des Marbres sections are thus key to unravel the early stages of the

637 Pyrenean shortening with two stages, a first thin-skinned episode with decollement of the basin

638 above the Triassic evaporites and a second thick-skinned episode leading to the present-day

639 structure.

640 Conclusions

This article is protected by copyright. All rights reserved. 
641 The eastern North Pyrenean Zone is thus an ideal locality to study the tectonic inversion and

642 integration of hyperextended rifted system (Internal Metamorphic Zone), associated with a pre-

643 rift decoupling layer, in an orogenic belt. By applying structural data and measured maximum

644 temperatures $\left(T_{\max }\right)$ estimated with the Raman Spectroscopy of Carbonaceous Materials

645 (RSCM) method, we show that a pre-kinematic decoupling layer has strongly impacted the

646 architecture of the Pyrenean belt, as well as the disposition of its sedimentary basins.

647 Concerning the thermal pattern, the Agly massif corresponded to a basement block separating

648 two metamorphic areas, the Boucheville syncline to the south and the Bas-Agly syncline to the

649 north. The Bas-Agly and Boucheville synclines are both affected by the Cretaceous HT/LP

650 metamorphism with $T_{\max }$ exceeding $550^{\circ} \mathrm{C}$. Remnants of Mesozoic sediments observed on top

651 of the Agly massif is also affected by the HT/LP Pyrenean metamorphism with temperature

652 higher than $400^{\circ} \mathrm{C}$ but lower than in the Bas Agly syncline. A strong thermal contrast exists

653 between the Bas-Agly/Boucheville synclines and the St-Paul-de-Fenouillet syncline located to

654 the north. A thermal gap is also observed between Bas-Agly/Boucheville synclines and the

655 northeastern part of the Agly massif.

656 Structural observations confirm the $T_{\max }$ distribution measured in the Agly massif and Bas-Agly

657 syncline. The northeast part of the Agly massif composed by Silurian to Devonian shales

658 exposed various brittle and brittle-ductile shears without no pervasive ductile deformation,

659 while the Mesozoic sediments of the Bas-Agly syncline show an intense ductile deformation

660 with metric-scale boudinage and recumbent metric folds.

661 To explain thermal and structural gaps and the similarities between the Boucheville and Bas-

662 Agly synclines, we propose that the Bas-Agly syncline may correspond to an allochthonous 663 unit thrusted northward on top of the Agly massif and the St-Paul-de-Fenouillet syncline during 664 early stages of horizontal shortening (thin-skinned tectonics). The pre-orogenic Upper Triassic

This article is protected by copyright. All rights reserved. 
evaporites decoupling layer and the low-angle normal faults inherited from the early Cretaceous

666 rifting allowed the transport of the Mesozoic cover above a north-verging thrust and the

667 substitution of the normal cover of the Agly massif by the metamorphic Bas-Agly syncline.

668 Consequently, the Boucheville and Bas-Agly basins were initially parts of a single basin during

669 the hyperextension rifting phase.

670 Acknowledgments

671 All the data used in this paper can be obtained in the figures, references, and supporting

672 information. Additionally, these data are deposed in repository (PANGEA) at

673 https://doi.pangaea.de/10.1594/PANGAEA.930199. The authors thank Stefano Tavani and an

674 anonymous reviewer for thorough, thought-provoking reviews that substantially improved their

675 initial submission. The authors also wish to thank Tectonics Editor Taylor Schildgen and

676 Associate Editor Federico Rossetti for their comments and editorial support. This work has

677 received funding from the Labex Voltaire and from the Institut Universitaire de France. It is a

678 contribution of the Labex VOLTAIRE. This work was realized within the scope of the

679 "Référentiel Géologique de la France" (RGF) funded by the French geological survey (BRGM).

680 The authors are grateful to S. Janiec and J.G. Badin (ISTO) for the preparation of thin sections,

681 A. Lahfid for precious helpful and advice for the Raman spectrometry. Many thanks to Charles

682 Gumiaux, Jean-Claude Ringenbach, Etienne Legeay, Julie Tugend, Geoffroy Mohn and

683 William Vetel for their help and fruitful discussions on the field.

\section{References}

Angrand, P., Ford, M., \& Watts, A. B. (2018). Lateral variations in foreland flexure of a rifted continental margin: The Aquitaine Basin (SW France). Tectonics, 37(2), 430-449.

Azambre, B., Rossy, M., 1976. Le magmatisme alcalin d'age cretace, dans les Pyrenees occidentales et l'Arc basque; ses relations avec le metamorphisme et la tectonique. Bull. Soc. Geol. Fr. S7-XVIII, 1725-1728. doi:10.2113/gssgfbull.S7-XVIII.6.1725

Barnolas, A., Chiron, J. C., \& Guérangé, B. (Eds.) (1996). Synthèse géologique et géophysique des Pyrénées: géophysique: cycle hercynien. Orléans, France: BRGM.

This article is protected by copyright. All rights reserved. 
Beaumont, C., J. A. Muñoz, J. Hamilton, and P. Fullsack (2000), Factors controlling the Alpine evolution of the central Pyrenees inferred from a comparison of observations and geodynamical models, J. Geophys. Res., 105(B4), 8121-8145, doi:10.1029/1999JB900390.

Bellahsen, N., Jolivet, L., Lacombe, O., Bellanger, M., Boutoux, A., Garcia, S., Mouthereau, F., Le Pourhiet, L., Gumiaux, C., 2012. Mechanisms of margin inversion in the external Western Alps; implications for crustal rheology. Tectonophysics 560-561, 62-83. doi:10.1016/j.tecto.2012.06.022

Bellanger, M., Bellahsen, N., Jolivet, L., Baudin, T., Augier, R., Boutoux, A., 2014. Basement shear zones development and shortening kinematics in the Ecrins Massif, Western Alps. Tectonics 33, 84-111. doi:10.1002/2013TC003294

Berger, G.M., Bessière, G., Bilotte, M., Viallard, P., 1997. Carte géologique de la France (1/50 000), feuille Tuchan (1078), Bureau de recherches géologiques et minières, Orléans.

Berger, G.M., Fonteilles, M., Leblanc, D., Clauzon, G., Marchal, J.-P., Vautrelle C., 1993. Notice explicative de la carte géologique de la France au 1/50.000, feuille de Rivesaltes (1090), 119 pp., BRGM, Orléans.

Bernus-Maury, C., 1984. Etude des paragenèses caractéristiques du métamorphisme mésozoïque dans la partie orientale des Pyrénées (French). Paris 6.

Bessière, G., Bilotte, M., Crochet, B., Peybernès, B., Tambareau, Y., Villate, J., 1989. Notice explicative de la carte géologique de la France au 1/50.000, feuille de Quillan (1077), 98 pp., BRGM, Orléans.

Beyssac, O., Goffé, B., Chopin, C., Rouzaud, J.N., 2002. Raman spectra of carbonaceous material in metasediments: a new geothermometer. J. Metamorph. Geol. 20, 859-871. doi:10.1046/j.1525-1314.2002.00408.x

Beyssac, O., Rouzaud, J.-N., Goffé, B., Brunet, F., Chopin, C., 2002. Graphitization in a highpressure, low-temperature metamorphic gradient: a Raman microspectroscopy and HRTEM study. Contrib. Mineral. Petrol. 143, 19.

Bles, J.L., Berger, G.M., 1982. Carte géologique de la France (1/50 000), feuille Leucate (1079), Bureau de recherches géologiques et minières, Orléans.

Bosch, G., Teixell, A., Jolivet, M., Labaume, P., Stockli, D., Domènech, M., \& Monié, P. (2016). Timing of Eocene-Miocene thrust activity in the Western Axial Zone and Chaînons Béarnais (west-Central Pyrenees) revealed by multi-method thermochronology. Comptes Rendus Geoscience, 348(3-4), 246-256. https://doi.org/10.1016/j.crte.2016.01.001

Bouhallier, H., Choukroune, P., Ballevre, M., 1991. Evolution structurale de la croûte profonde hercynienne: exemple du massif de l'Agly (pyrenees orientales, france). Comptes Rendus Académie Sci. Sér. 2 Mécanique Phys. Chim. Sci. Univers Sci. Terre 312, 647654.

Branellec, M., Niviere, B., Callot, J. P., \& Ringenbach, J. C. (2016). Mechanisms of basin contraction and reactivation in the basement-involved Malargüe fold-and-thrust belt, Central Andes (34-36 S). Geological Magazine, 153(5-6), 926-944.

Brown, D., Alvarez-Marron, J., Perez-Estaun, A., Puchkov, V., Ayala, C., 1999. Basement influence on foreland thrust and fold belt development; an example from the Southern Urals. Tectonophysics 308, 459-472.

This article is protected by copyright. All rights reserved. 
Canérot, J., 2016. The Iberian Plate: myth or reality? Bol. Geológico Min. 127, 563-574.

Canérot, J., 2008. Les Pyrénées: histoire géologique et itinéraires de découvertes, AtlanticaBRGM éditions. ed.

Canérot, J., 1988. Manifestations de l'halocinèse dans les chaînons béarnais (zone NordPyrénéenne) au Crétacé inférieur. Comptes Rendus Académie Sci. Sér. 2 Mécanique Phys. Chim. Sci. Univers Sci. Terre 306, 1099-1102.

Canérot, J., Lenoble, J.L., 1993. Diapirisme cretace sur la marge iberique des Pyrenees occidentales; exemple du pic de Lauriolle; comparaisons avec l'Aquitaine, les Pyrenees centrales et orientales. Bull. Société Géologique Fr. 164, 719-726.

Casas, J. M., \& Palacios, T. (2012). First biostratigraphical constraints on the pre-Upper Ordovician sequences of the Pyrenees based on organic-walled microfossils. Comptes Rendus Geoscience, 344(1), 50-56.

Chelalou, R., 2015. Formation et évolution du bassin de Boucheville, implication sur l'évolution tectonique, métamorphique et sédimentaire des bassins sédimentaires mésozoïques du Nord-Est des Pyrénées (phdthesis). Université Rennes 1.

Chelalou, R., Nalpas, T., Bousquet, R., Prevost, M., Lahfid, A., Poujol, M., Ringenbach, J.-C., Ballard, J.-F., 2016. New sedimentological, structural and paleo-thermicity data in the Boucheville Basin (eastern North Pyrenean Zone, France). Comptes Rendus Géoscience 348, 312-321. doi:10.1016/j.crte.2015.11.008

Chevrot, S., Sylvander, M., Diaz, J., Martin, R., Mouthereau, F., Manatschal, G., ... \& Ruiz, M. (2018). The non-cylindrical crustal architecture of the Pyrenees. Scientific reports, 8(1), $1-8$.

Choukroune, P., 1976. Structure et évolution tectonique de la zone nord-pyrénéenne: analyse de la déformation dans une portion de chaîne à schistosité sub-verticale. Société géologique de France, Paris.

Choukroune, P., 1970. Contribution a l'etude structurale de la zone metamorphique nordpyreneenne; tectonique et metamorphisme des formations secondaires de la foret de Boucheville (P.-O.); feuille au 1/50 000 Saint-Paul-de-Fenouillet. Struct. Metamorp 4, 49-63.

Choukroune, P., ECORS Team, 1989. The ECORS Pyrenean deep seismic profile reflection data and the overall structure of an orogenic belt. Tectonics 8, 23-39.

Choukroune, P., Pinet, B., Roure, F., Cazes, M., 1990a. Major Hercynian thrusts along the ECORS Pyrenees and Biscay lines. Bull. Soc. Geol. Fr. 6, 313-320.

Choukroune, P., Mattauer, M., 1978. Tectonique des plaques et Pyrenees: sur le fonctionnement de la faille transformante nord-pyreneenne; comparaisons avec des modeles actuels. Plate Tecton. Pyrenees Action North. Pyrenean Transform Fault Comp. 20, 689-700.

Clerc, C., Boulvais, P., Lagabrielle, Y., de St Blanquat, M., 2013. Ophicalcites from the northern Pyrenean belt: a field, petrographic and stable isotope study. Int. J. Earth Sci. 103, 141-163. doi:10.1007/s00531-013-0927-z

Clerc, C., Lagabrielle, Y., 2014. Thermal control on the modes of crustal thinning leading to mantle exhumation: Insights from the Cretaceous Pyrenean hot paleomargins. Tectonics 33, 2013TC003471. doi:10.1002/2013TC003471

Clerc, C., Lagabrielle, Y., Labaume, P., Ringenbach, J.-C., Vauchez, A., Nalpas, T., Bousquet, R., Ballard, J.-F., Lahfid, A., Fourcade, S., 2016. Basement - Cover decoupling and

This article is protected by copyright. All rights reserved. 
progressive exhumation of metamorphic sediments at hot rifted margin. Insights from

the Northeastern Pyrenean analog. Tectonophysics 686, 82-97. doi:10.1016/j.tecto.2016.07.022

Clerc, C., Lagabrielle, Y., Neumaier, M., Reynaud, J.-Y., de Saint Blanquat, M., 2012. Exhumation of subcontinental mantle rocks: evidence from ultramafic-bearing clastic deposits nearby the Lherz peridotite body, French Pyrenees. Bull. Soc. Geol. Fr. 183, 443-459.

Clerc, C., Lahfid, A., Monie, P., Lagabrielle, Y., Chopin, C., Poujol, M., Boulvais, P., Ringenbach, J.-C., Masini, E., de St Blanquat, M., 2015. High-temperature metamorphism during extreme thinning of the continental crust: a reappraisal of the North Pyrenean passive paleomargin. Solid Earth 6, 643-668. doi:10.5194/se-6-6432015

Costa, S., Maluski, H., 1988. Use of the 40Ar- 39Ar stepwise heating method for dating mylonite zones: An example from the St. Barthe'le'my massif (Northern Pyrenees, France). Chem. Geol. Isot. Geosci. Sect. 72, 127-144. doi:10.1016/01689622(88)90061-9

Coleman, A. J., Duffy, O. B., \& Jackson, C. A. L., 2019, Growth folds above propagating normal faults. Earth-Science Reviews, 102885.

Crittenden, M.D., Coney, P.J., Davis, G.H., 1980. Cordilleran metamorphic core complexes. Geol. Soc. Am. 490.

Crochet, B., Villate, J., Tambareau, Y., Bilotte, M., Bousquet, J.-P., Kuhfuss, A., Bouillin, J.P., Gélard, J.-P., Bessière, G., Paris, J.-P., 1989. Carte géologique de la France (1/50 000), feuille Quillan (1077), Bureau de recherches géologiques et minières, Orléans.

Dauteuil, O., Ricou, L.E., 1989. Une circulation de fluides de haute-temperature a l'origine du metamorphisme cretace nord-pyreneen. Circ. High-Temp. Fluids Orig. North Pyrenean Cretac. Metamorph. 3, 237-250.

Davis, G.A., Lister, G.S., 1988. Detachment faulting in continental extension; Perspectives from the Southwestern U.S. Cordillera. Geol. Soc. Am. Spec. Pap. 218, 133-160. doi:10.1130/SPE218-p133

De Saint Blanquat, M., Lardeaux, J.M., Brunel, M., 1990. Petrological arguments for hightemperature extensional deformation in the Pyrenean Variscan crust (Saint Barthélémy massif, Ariège, France). Tectonophysics 177, 245-262. doi:10.1016/00401951(90)90284-F

Debroas, E.J., 1990. Le flysch noir albo-cenomanien temoin de la structuration albienne a senonienne de la Zone nord-pyreneenne en Bigorre (Hautes-Pyrenees, France). Bull. Société Géologique Fr. 6, 273-285.

Debroas, E.J., 1987. Le flysch a fucoides d'Uchentein temoin d'un escarpement turonosenonien inferieur de la paleofaille nord-pyreneenne, Pyrenees centrales, France. Fucoidal Flysch Uchentein Indic. Turonian-Low. Senonian Escarpm. Of 3, 77-93.

Delay, F. (1990). Etude structurale du massif de l'Agly (Pyrénées orientales). Mémoires de la Société Géologique du Nord, 17.

Delay, F., \& Paquet, J. (1989). Tectonique ductile en extension dans le massif hercynien de l'Agly (zone nord-pyrénéenne): Comptes Rendus de l'Académie des Sciences) (Vol. 308, pp. 1637-1643).

This article is protected by copyright. All rights reserved. 
Desegaulx, P., \& Brunet, M. F. (1990). Tectonic subsidence of the Aquitaine basin since Cretaceous times. Bulletin de la Société géologique de France, 8, 295-306.

Domènech, M., Teixell, A., Stockli, D.F., 2016. Magnitude of rift-related burial and orogenic contraction in the Marrakech High Atlas revealed by zircon (U-Th)/He thermochronology and thermal modeling. Tectonics 35, $2016 \mathrm{TC} 004283$. doi:10.1002/2016TC004283

Ducoux, M. (2017). Structure, thermicité et évolution géodynamique de la Zone Interne Métamorphique des Pyrénées (Doctoral dissertation).

Ducoux, Maxime; Jolivet, Laurent (2021): Peak metamorphic temperatures (Tmax) from the eastern Pyrenees. PANGAEA, https://doi.pangaea.de/10.1594/PANGAEA.930199 (DOI registration in progress)

Ducoux, M., Jolivet, L., Callot, J-P., Aubourg, C., Masini, E., Lahfid, A., Homonnay, E., Cagnard, F., Gumiaux, C., \& Baudin, T., 2019. The Nappe des Marbres unit of the Basque-Cantabrian Basin: the tectono-thermal evolution of a fossil hyperextended rift basin. Tectonics, ...

Durand-Delga, M., 1964. Remarques sur la stratigraphie et la structure du Mésozoïque situé entre Estagel et Perpignan (Pyrénées-Orientales). C. R. Acad. Sci. Paris 259, 837-840.

Duretz, T., Asti, R., Lagabrielle, Y., Brun, J. P., Jourdon, A., Clerc, C., \& Corre, B. (2019). Numerical modelling of Cretaceous Pyrenean Rifting: The interaction between mantle exhumation and syn - rift salt tectonics. Basin Research.

Etheve, N., Mohn, G., Frizon de Lamotte, D., Roca, E., Tugend, J., \& Gómez-Romeu, J., 2018. Extreme Mesozoic Crustal Thinning in the Eastern Iberia Margin: The Example of the Columbrets Basin (Valencia Trough). Tectonics, 37(2), 636-662.

Ferrer, O., Roca, E., Jackson, M.P.A., Muñoz, J.A., 2009. Effects of Pyrenean contraction on salt structures of the offshore Parentis Basin (Bay of Biscay). Trab. Geol. 29. doi:10.17811/tdg.29.2009.\%p

Fitzgerald, P.G., Muñoz, J.A., Coney, P.J., Baldwin, S.L., 1999. Asymmetric exhumation across the Pyrenean orogen: implications for the tectonic evolution of a collisional orogen. Earth Planet. Sci. Lett. 173, 157-170. doi:10.1016/S0012-821X(99)00225-3

Fonteilles, M. (1970). Géologie des terrains métamorphiques et granitiques du massif hercynien de l'Agly (Pyrénées orientales). Bulletin de la Bureau de Récherches Géologiques et Minéralogiques, 2, 21-72.

Fonteilles, M., Leblanc, D., Clauzon, G., Vaudin, J.-L., Berger, G.M., 1993. Carte géologique de la France (1/50 000), feuille Rivesaltes (1090), Bureau de recherches géologiques et minières, Orléans.

Froitzheim, N., Stets, J., Wurster, P., 1988. Aspects of Western High Atlas tectonics, in: In: Jacobshagen, V. (Ed.), The Atlas System of Morocco, Lecture Notes in Earth Sciences. Springer, Berlin, Heidelberg, pp. 219-244. doi:10.1007/BFb0011595

Garrido-Megias, A., Rios Aragues, L.M. (super a), 1972. Sintesis geologica del Secundario y Terciario entre los rios Cinca y Segre (Pirineo Central de la vertiente sur pirenaica, provincias de Huesca y Lerida). Summ. Mesoz. Tert. Geol. Cinca Segre Rivers Souther $83,1-47$.

This article is protected by copyright. All rights reserved. 
Golberg, J.M., 1987. Le metamorphisme mesozoique dans la partie orientale des Pyrenees; relations avec l'evolution de la chaine au cretace. Universite des Sciences et Techniques du Languedoc, Centre Geologique et Geophysique : Montpellier, France, France.

Golberg, J.M., Leyreloup, A.F., 1990. High temperature-low pressure Cretaceous metamorphism related to crustal thinning (Eastern North Pyrenean Zone, France). Contrib. Mineral. Petrol. 104, 194-207. doi:10.1007/BF00306443

Gómez-Romeu, J., Masini, E., Tugend, J., Ducoux, M., \& Kusznir, N. (2019). Role of rift structural inheritance in orogeny highlighted by the Western Pyrenees case-study. Tectonophysics.

Gorini, C., Le Marrec, A., Mauffret, A., 1993. Contribution to the structural and sedimentary history of the Gulf of Lions (western Mediterranean), from the ECORS profiles, industrial seismic pro-files and weIl data. Bull. Geol. Soc. France 164,353-363.

Gorini, C., Mauffret, A., Guennoc, P., Le Marrec, A., 1994. Structure of the Gulf of Lions (Northwestern Mediterranean Sea): a review. In: Mascle, A. (Ed.), Hydrocarbon and Petroleum Geology of France. Springer-Verlag, pp. 223-243.

Grool, A. R., Ford, M., Vergés, J., Huismans, R. S., Christophoul, F., \& Dielforder, A. (2018). Insights into the crustal-scale dynamics of a doubly vergent orogen from a quantitative analysis of its forelands: A case study of the eastern Pyrenees. Tectonics, 37, 450-476. https://doi.org/10.1002/2017TC004731

Guille, B. T., Olivier, P., Paquette, J. L., Bosse, V., \& Guillaume, D. (2019). Evolution of the middle crust of the Pyrenees during the Paleozoic: new data on the plutonic rocks from the North Pyrenean Agly massif. International Journal of Earth Sciences, 108(1), 245265.

Gunnell, Y., Calvet, M., Brichau, S., Carter, A., Aguilar, J.-P., Zeyen, H., 2009. Low long-term erosion rates in high-energy mountain belts: Insights from thermo- and biochronology in the Eastern Pyrenees. Earth Planet. Sci. Lett. 278, 208-218. doi:10.1016/j.eps1.2008.12.004

Hogan, P. J., and K. D. W. Burbank (1996), Evolution of the Jaca piggy-back basin and emergence of the External Sierras, southern Pyrenees, in Tertiary Basins of Spain, edited by P. F. Friend and C. J. Dabrio, pp. 153-160, Cambridge Univ. Press, Cambridge, U. K.

Izquierdo - Llavall, E., Menant, A., Aubourg, C., Callot, J. P., Hoareau, G., Camps, P., ... \& Lahfid, A. Pre - orogenic folds and syn - orogenic basement tilts in an inverted hyperextended margin: the northern Pyrenees case study. Tectonics, e2019TC005719.

Jackson, M. P. A., \& Vendeville, B. C. (1994). Regional extension as a geologic trigger for diapirism. Geological society of America bulletin, 106(1), 57-73.

James, V., Canerot, J., 1999. Diapirisme et structuration post-triasique des Pyrénées occidentale et de l'Aquitaine méridionale (France). Eclogae Geol. Helvetiae 63. doi:10.5169/seals168647

Jammes, S., Manatschal, G., Lavier, L., 2010. Interaction between prerift salt and detachment faulting in hyperextended rift systems: The example of the Parentis and Mauléon basins (Bay of Biscay and western Pyrenees). AAPG Bull., 2010b 94, 957-975. doi:10.1306/12090909116

This article is protected by copyright. All rights reserved. 
Jammes, S., Manatschal, G., Lavier, L., Masini, E., 2009. Tectonosedimentary evolution related to extreme crustal thinning ahead of a propagating ocean: Example of the western Pyrenees. Tectonics 28, TC4012. doi:10.1029/2008TC002406

Jolivet, L., Romagny, A., Gorini, C., Maillard, A., Thinon, I., Couëffé, R., Ducoux, M., Séranne, M., 2020. Fast dismantling of a mountain belt by mantle flow: late-orogenic evolution of Pyrenees and Liguro-Provençal rifting. Tectonophysics 776, 228312, doi.org/228310.221016/j.tecto.222019.228312.

Jolivet, M., Labaume, P., Monié, P., Brunel, M., Arnaud, N., Campani, M., 2007. Thermochronology constraints for the propagation sequence of the south Pyrenean basement thrust system (France-Spain). Tectonics 26, TC5007. https://doi.org/10.1029/2006TC002080.

Jourdon, A., Le Pourhiet, L., Mouthereau, F., \& Masini, E. (2019). Role of rift maturity on the architecture and shortening distribution in mountain belts. Earth and Planetary Science Letters, 512, 89-99.

Jourdon, A., Mouthereau, F., Le Pourhiet, L., \& Callot, J. P. (2020). Topographic and tectonic evolution of mountain belts controlled by salt thickness and rift architecture. Tectonics, 39(1), e2019TC005903.

Labaume, P., Meresse, F., Jolivet, M., \& Teixell, A. (2016). Exhumation sequence of the basement thrust units in the west-central Pyrenees. Constraints from apatite fission track analysis. Geogaceta, 60, 11-14.

Labaume, P., Teixell, A., 2020. Evolution of salt structures of the Pyrenean rift (Chaînons Béarnais, France): From hyper-extension to tectonic inversion. Tectonophysics, https://doi.org/10.1016/j.tecto.2020.228451.

Lacombe, O., and Bellahsen, N., 2016, Thick-skinned tectonics and basement-involved foldthrust belts: insights from selected Cenozoic orogens: Geological Magazine, v. 153, p. 763-810, doi:10.1017/S0016756816000078.

Lagabrielle, Y., Bodinier, J.-L., 2008. Submarine reworking of exhumed subcontinental mantle rocks; field evidence from the Lherz peridotites, French Pyrenees. Terra Nova 20, 1121. doi:10.1111/j.1365-3121.2007.00781.x

Lagabrielle, Y., Clerc, C., Vauchez, A., Lahfid, A., Labaume, P., Azambre, B., Fourcade, S., Dautria, J.-M., 2016. Very high geothermal gradient during mantle exhumation recorded in mylonitic marbles and carbonate breccias from a Mesozoic Pyrenean palaeomargin (Lherz area, North Pyrenean Zone, France). Comptes Rendus Geosci., From rifting to mountain building: the Pyrenean Belt 348, 290-300. doi:10.1016/j.crte.2015.11.004

Lagabrielle, Y., Labaume, P., de Saint Blanquat, M., 2010. Mantle exhumation, crustal denudation, and gravity tectonics during Cretaceous rifting in the Pyrenean realm (SW Europe): Insights from the geological setting of the lherzolite bodies. Tectonics 29, TC4012. doi:10.1029/2009TC002588

Lahfid, A., Beyssac, O., Deville, E., Negro, F., Chopin, C., Goffe, B., 2010. Evolution of the Raman spectrum of carbonaceous material in low-grade metasediments of the Glarus Alps (Switzerland). Terra Nova 22, 354-360. doi:10.1111/j.1365-3121.2010.00956.x

Légier, C., Tempier, C., Vauchez, A., 1987. Tectoniques tangentielle ductile synmétamorphe d'âge Crétacé supérieur dans la couverture du massif de l'Agly (zone Nord-pyrénéenne orientale). C. R. Acad. Sci. Paris 305, 907-911.

This article is protected by copyright. All rights reserved. 
Lemoine, M., bas, T., Arnaud-Vanneau, A., Arnaud, H., Dumont, T., Gidon, M., Bourbon, M., de Graziansky, P.C., Rudkiewicz, J.L., Mégard-Galli, J., 1986. The continental margin of the mesozoic tethys in the western alps. Marine and petroleum geology 3, 179-199.

Lescoutre, R., \& Manatschal, G. (2020). Role of rift-inheritance and segmentation for orogenic evolution: example from the Pyrenean-Cantabrian systemRôle de l'héritage associé au rift et à sa segmentation pour l'évolution orogénique: exemple du système pyrénéocantabrique. Bulletin de la Société Géologique de France, 191(1). https://doi.org/10.1051/bsgf/2020021

Letouzey, J., 1990. Fault reactivation, inversion and foldthrust belt, in Petroleum and tectonics in Mobile Belts, edited by J. Letouzey. Tech. Paris 101-128.

Lopez-Mir, B., Muñoz, J. A., \& Senz, J. G. (2014). Restoration of basins driven by extension and salt tectonics: Example from the Cotiella Basin in the central Pyrenees. Journal of Structural Geology, 69, 147-162.

Lundin, E.R., Doré, A.G., 2011. Hyperextension, serpentinization, and weakening: a new paradigm for rifted margin compressional deformation. Geology 39, 347-350. https://doi.org/10.1130/G31499.1.

Manatschal, G., Lavier, L., \& Chenin, P. (2015). The role of inheritance in structuring hyperextended rift systems: Some considerations based on observations and numerical modeling. Gondwana Research, 27(1), 140-164.

Martinez-Peña, M., and A. Casas-Sainz (2003), Cretaceous-Tertiary tectonic inversion of the Cotiella Basin (southern Pyrenees, Spain), Int. J. Earth Sci. (Geol. Rundsch.), 92(1), 99113, doi:10.1007/s00531-002-0283-x.

Masini, E., Manatschal, G., Tugend, J., Mohn, G., Flament, J.-M., 2014. The tectonosedimentary evolution of a hyper-extended rift basin; the example of the ArzacqMauleon rift system (western Pyrenees, SW France). Int. J. Earth Sci. Geol. Rundsch. 103, 1569-1596. doi:10.1007/s00531-014-1023-8

Mattauer, M., 1968. Les traits structuraux essentiels de la Chaîne des Pyrenées. Essent. Struct. Traits Pyrenees 10, 3-11.

Mauffret, A., Pascal, G., Maillard, A., Gorini, C., 1995. Tectonics and deep structure of the north-western Mediterranean basin. Mar. Pet. Geol. 12, 645-666.

Mauffret, A., Durand de Grossouvre, B., Dos Reis, A.T., Gorini, C., Nercessian, A., 2001. Structural geometry in the eastern Pyrenees and western Gulf of Lion (Western Mediterranean). J. Struct. Geol. 23, 1701-1726.

McClay, K., Munoz, J.-A., Garcia-Senz, J., 2004. Extensional salt tectonics in a contractional orogen; a newly identified tectonic event in the Spanish Pyrenees. Geol. Boulder 32, 737-740. doi:10.1130/G20565.1

Michard, A.V., Allègre, C.J., 1975. A study of the formation and history of a piece of continental crust by $87 \mathrm{Rb}-87 \mathrm{Sr}$ method: The case of the French oriental Pyrénées. Contrib. Mineral. Petrol. 50, 257-285. doi:10.1007/BF00394853

Millán Garrido, H. (2006), Estructura y cinemática del frente de cabalgamiento surpirenaico en las Sierras Exteriores aragonesas, in Colección de Estudios Altoaragoneses, vol. 53, Instituto de Estudios Altoaragoneses, Huesca, Spain.

Millán Garrido, H., E. L. Pueyo Morer, M. Aurell Cardona, A. Aguado Luzón, B. Oliva Urcia, M. B. Martínez Peña, and A. Pocoví (2000), Actividad tectonica registrada en los

This article is protected by copyright. All rights reserved. 
depósitos terciarios del frente meridional del Pirineo central, Rev. Soc. Geol. Esp., 13, 279-300.

Mouthereau, F., Watts, A.B., Burov, E., 2013. Structure of orogenic belts controlled by lithosphere age. Nat. Geosci. 6, 785-789. doi:10.1038/ngeo1902

Mouthereau, F., Filleaudeau, P.-Y., Vacherat, A., Pik, R., Lacombe, O., Fellin, M.G., Castelltort, S., Christophoul, F., Masini, E., 2014. Placing limits to shortening evolution in the Pyrenees: Role of margin architecture and implications for the Iberia/Europe convergence. Tectonics 33, 2014TC003663. doi:10.1002/2014TC003663

Mitra, S., Mount, V.S., 1998. Foreland Basement-Involved Structures. AAPG Bull. 82, 70-109.

Muñoz, J.A., 1992. Evolution of a continental collision belt; ECORS-Pyrenees crustal balanced cross-section. In: MCCLAY, K. R. (ed) Thrust tectonics. Chapman \& Hall : London, United Kingdom, pp. 235-246.

Muñoz, J.A., 2002. The Pyrenees. In: GIBBONS, W. \& MORENO, M. T. (eds) The geology of Spain. Geological Society, London, p. 370-385.

Muñoz, J.A., Beamud, E., Fernández, O., Arbués, P., Dinarès-Turell, J., and Poblet, J., 2013, The Ainsa Fold and thrust oblique zone of the central Pyrenees: Kinematics of a curved contractional system from paleomagnetic and structural data: Tectonics, v. 32, p. 1-34, doi:10.1002/tect.20070.

Odlum, M. L., \& Stockli, D. F. (2019). Thermotectonic evolution of the North Pyrenean Agly massif during Early Cretaceous hyperextension using multi-mineral U-Pb thermochronometry. Tectonics, 38, 1509-1531. https://doi.org/10.1029/2018TC005298

Oliva-Urcia, B., E. Beamud, M. Garcés, C. Arenas, R. Soto, E. L. Pueyo, and G. Pardo (2015), New magnetostratigraphic dating in the Palaeogene syntectonic sediments of the westcentral Pyrenees: Tectonostratigraphic implications, in Palaeomagnetism in Fold and Thrust Belts: New Perpectives, edited by E. L. Pueyo, Geol. Soc. Spec. Publ., 425, doi:10.1144/SP425.5.

Olivier, P., Gleizes, G., Paquette, J.L., 2004. Gneiss domes and granite emplacement in an obliquely convergent regime: New interpretation of the Variscan Agly massif (Eastern Pyrenees, France). Geol. Soc. Am. Spec. Pap. 380, 229-242. doi:10.1130/0-8137-23809.229

Olivier, P., Gleizes, G., Paquette, J.-L., Sáez, C.M., 2008. Structure and U-Pb dating of the Saint-Arnac pluton and the Ansignan charnockite (Agly massif): a cross-section from the upper to the middle crust of the Variscan Eastern Pyrenees. J. Geol. Soc. 165, 141152. doi:10.1144/0016-76492006-185

Olivier, P. (2013), Comment on "Preorogenic exhumation of the North Pyrenean Agly massif (Eastern Pyrenees-France)" by A. Vauchez et al., Tectonics, 32, 821-822, doi:10.1002/tect.20049

Ortiz, A., Guillocheau, F., Lasseur, E., Briais, J., Robin, C., Serrano, O., \& Fillon, C., 2020, Sediment routing system and sink preservation during the post-orogenic evolution of a retro-foreland basin: The case example of the North Pyrenean (Aquitaine, Bay of Biscay) Basins. Marine and Petroleum Geology, 112, 104085.

Paquet, J., Mansy, J.-L., 1991. La structure de 1'Est des Pyrénées (transversales du massif de l'Agly) : un exemple d'amincissement crustal. Comptes Rendus Académie Sci. Sér. 2 Mécanique Phys. Chim. Sci. Univers Sci. Terre 312, 913-919.

This article is protected by copyright. All rights reserved. 
1043

1044

1045

1046

1047

1048

1049

1050

1051

1052

1053

1054

1055

1056

1057

1058

1059

1060

1061

1062

1063

1064

1065

1066

1067

1068

1069

1070

1071

1072

1073

1074

1075

1076

1077

1078

1079

1080

1081

1082

1083

1084

1085

1086

Passchier, C.W., 1984. Mylonite-dominated footwall geometry in a shear zone, central Pyrenees. Geol. Mag. 121, 429-436. doi:10.1017/S0016756800029964

Pasteris, J., Wopenka, B., 1991. Raman-Spectra of Graphite as Indicators of Degree of Metamorphism. Can. Mineral. 29, 1-9.

Pasteris, J.D., 1989. In situ analysis in geological thin-sections by laser Raman microprobe spectroscopy; a cautionary note. Appl. Spectrosc. 567-570.

Pérez-Gussinyé, M., Reston, T.J., Phipps Morgan, J., 2001. Serpentinization and magmatism during extension at non-volcanic margins: the effect of initial lithospheric structure. Geol. Soc. London, Spec. Publ. 187, 551-576. https://doi.org/10.1144/GSL.SP.2001.187.01.27.

Péron-Pinvidic, G., Manatschal, G., Dean, S.M., Minshull, T.A., 2008. Compressional structures on the West Iberia rifted margin: Controls on their distribution. In:Johnson, H. (Ed.), The Nature and Origin of Compression in Passive Margins. Geol.Soc. London, Spec. Publ. vol. 306. pp. 169-183. https://doi.org/10.1144/SP306.8.

Pfiffner, O.A., 2017, Thick-Skinned and Thin-Skinned Tectonics: A Global Perspective: Geosciences, v. 7, p. 71, doi:10.3390/geosciences7030071.

Poujol, M., Boulvais, P., Kosler, J., 2010. Regional-scale Cretaceous albitization in the Pyrenees: evidence from in situ $\mathrm{U}-\mathrm{Th}-\mathrm{Pb}$ dating of monazite, titanite and zircon. J. Geol. Soc. 167, 751-767. doi:10.1144/0016-76492009-144

Ravier, J., 1959. Le metamorphisme des terrains secondaires des Pyrenees. Memoires Soc. Geol. Fr. Nouv. Ser. 38.

Roca, E., 2001. The Northwest Mediterranean Basin (Valencia Trough, gulf of Lions and Liguro-Provençal basins): structure and geodynamic evolution, in Ziegler, P. A., Cavazza, W., Robertson, A. H. F., and Crasquin-Soleau, S., eds., Peri-Tethys Memoir 6: Pery-Tethyan Rift/Wrench Basins and Passive Margins. Mémoires Muséum National d'HistoireNaturelle, 186: Paris, 671-706.

Roca, E., Sans, M., Cabrera, L., Marzo, M., 1999. Oligocene to Middle Miocene evolution of the central Catalan margin (northwestern Mediterranean). Tectonophysics 315, 209229. doi:10.1016/S0040-1951(99)00289-9

Roure, F., P. Choukroune, X. Beràstegui, J. A. Muñoz, A. Villien, P. Matheron, M. Bareyt, M. Séguret, P. Camara, and J. Déramond (1989), ECORS deep seismic data and balanced cross sections: Geometric constraints on the evolution of the Pyrenees, Tectonics, 8(1), 41-50, doi:10.1029/TC008i001p00041.

Rowan, M.G., 2014, Passive-margin salt basins; hyperextension, evaporite deposition, and salt tectonics. Basin Res. 26, 154-182. doi:10.1111/bre.12043

Rushlow, C.R., Barnes, J.B., Ehlers, T.A., Vergés, J., 2013. Exhumation of the southern Pyrenean fold-thrust belt (Spain) from orogenic growth to decay. Tectonics 32, 843860. doi:10.1002/tect.20030

Saura, E., L. Ardèvol i Oró, A. Teixell, and J. Vergés (2016), Rising and falling diapirs, shifting depocenters, and flap overturning in the Cretaceous Sopeira and Sant Gervàs subbasins (Ribagorça Basin, southern Pyrenees), Tectonics, 35, 638-662, doi:10.1002/2015TC004001.

Scharf, A., Handy, M.R., Ziemann, M.A., Schmid, S.M., 2013. Peak-temperature patterns of polyphase metamorphism resulting from accretion, subduction and collision (eastern

This article is protected by copyright. All rights reserved. 
Tauern Window, European Alps); a study with Raman microspectroscopy on carbonaceous material (RSCM). J. Metamorph. Geol. 31, 863-880. doi:10.1111/jmg.12048

Tavani, S., Camanni, G., Nappo, M., Snidero, M., Ascione, A., Valente, E., Gharabeigli, G., Morsalnejad, D., and Mazzoli, S., 2020, The Mountain Front Flexure in the Lurestan region of the Zagros belt: Crustal architecture and role of structural inheritances: Journal of Structural Geology, v. 135, p. 104022, doi:10.1016/j.jsg.2020.104022.

Ternet, Y., Colchen, M., Debroas, E.-J., Azambre, B., Debon, F., Bouchez, J.L., Gleizes, G., Leblanc, D., Bakalowicz, M., Jauzion, G., Mangin, A., Soulé, J.-C., 1997. Notice explicative de la carte géologique de la France au 1/50.000, feuille de Aulus-les-Bains (1086), 146 pp., BRGM, Orléans.

Ternois, S., Odlum, M., Ford, M., Pik, R., Stockli, D., Tibari, B., et al. (2019). Thermochronological evidence of early orogenesis, eastern Pyrenees, France. Tectonics, 38, 1308-1336. https://doi.org/10.1029/2018TC005254

Teixell, A. (1996), The Ansó transect of the southern Pyrenees: Basement and cover thrust geometries, J. Geol. Soc., 153, 301-310.

Teixell, A. (1998), Crustal structure and orogenic material budget in the west central Pyrenees, Tectonics, 17(3), 395-406, doi:10.1029/98TC00561.

Teixell, A., Labaume, P., \& Lagabrielle, Y., 2016, The crustal evolution of the west-central Pyrenees revisited: inferences from a new kinematic scenario. Comptes Rendus Geoscience, 348(3-4), 257-267.

Tugend, J., Manatschal, G., Kusznir, N.J., Masini, E., Mohn, G., Thinon, I., 2014. Formation and deformation of hyperextended rift systems; insights from rift domain mapping in the Bay of Biscay-Pyrenees. Tectonics 33, 1239-1276. doi:10.1002/2014TC003529

Tugend, J., Manatschal, G., Kusznir, N.J., 2015. Spatial and temporal evolution of hyperextended rift systems: Implication for the nature, kinematics, and timing of the Iberian- European plate boundary. Geology 15-18. https://doi.org/10.1130/G36072.1.

Vacherat, A., Mouthereau, F., Pik, R., Bellahsen, N., Gautheron, C., Bernet, M., Daudet, M., Balansa, J., Tibari, B., Pinna Jamme, R., Radal, J., 2016. Rift-to-collision transition recorded by tectonothermal evolution of the northern Pyrenees. Tectonics 35, 907.

Vacherat, A., Mouthereau, F., Pik, R., Bernet, M., Gautheron, C., Masini, E., Le Pourhiet, L., Tibari, B., Lahfid, A., 2014. Thermal imprint of rift-related processes in orogens as recorded in the Pyrenees. Earth Planet. Sci. Lett. 408, 296-306. doi:10.1016/j.epsl.2014.10.014

Vanardois J, Trap P, Goncalves P, Marquer D, Gremmel J, Siron G, Baudin T. 2020. Kinematics, deformation partitioning and late Variscan magmatism in the Agly massif, Eastern Pyrenees, France, BSGF - Earth Sciences Bulletin 191: 15.

Vauchez, A., Clerc, C., Bestani, L., Lagabrielle, Y., Chauvet, A., Lahfid, A., Mainprice, D., 2013. Pre-orogenic exhumation of the north Pyrenean Agly massif (eastern Pyrenees, France). Tectonics 32, 95-106. doi:10.1002/tect.20015

Vergés, J., and García-Senz, J., 2001. Mesozoic evolution and Cainozoic inversion of the Pyrenean rift, in Peri-Tethyan Rift/Wrench Basins and Passive Margins, edited by P. A. Ziegler et al., mémoire, pp. 187-212, 
1130

1131

1132

1133

1134

1135

1136

1137

1138

1139

1140

1141

1142

1143

1144

1145

1146

1147

1148

1149

1150

1151

1152

1153 Figure 1: Simplified structural map of the Pyrenean belt. Only main "alpine" thrusts and faults

1154 are represented: North-Pyrenean Frontal Thrust (NPFT), South-Pyrenean Frontal Thrust

1155 (SPFT), and North-Pyrenean Fault. The Internal Metamorphic Zone (IMZ, orange in the figure)

1156 is located in the North Pyrenean Zone (NPZ) and crops out along the strike of the belt. The

1157 study area is located in the eastern part of this belt.

Verges, J., Fernandez, M., Martinez, A., 2002. The Pyrenean orogen; pre-, syn-, and postcollisional evolution. J. Virtual Explor. 8, 57-76.

Vielzeuf, D., and J. Kornprobst (1984), Crustal splitting and the emplacement of Pyrenean lherzolites and granulites, Earth Planet. Sci. Lett., 67(1), 87-96, doi:10.1016/0012821X(84)90041-4.

Watts, A.B., Lamb, S.H., Fairhead, J.D., Dewey, J.F., 1995. Lithospheric flexure and bending of the Central Andes. Earth Planet. Sci. Lett. 134, 9-21. doi:10.1016/0012821X(95)00095-T

Wehr, H., Chevrot, S., Courrioux, G., Guillen, A., 2018. A three-dimensional model of the Pyrenees and their foreland basins from geological and gravimetric data. Tectonophysics 734-735, 16-32; https://doi.org/10.1016/j.tecto.2018.1003.1017.

Whitchurch, A.L., Carter, A., Sinclair, H.D., Duller, R.A., Whittaker, A.C., Allen, P.A., 2011. Sediment routing system evolution within a diachronously uplifting orogen: Insights from detrital zircon thermochronological analyses from the South-Central Pyrenees. Am. J. Sci. 311, 442-482. doi:10.2475/05.2011.03

Wickham, S. M., \& Oxburgh, E. R. (1986). A rifted tectonic setting for Hercynian high thermal gradient metamorphism in the Pyrenees. Tectonophysics, 129(1-4), 53-69. https://doi.org/10.1016/0040 - 1951(86)90245 - 3

Wopenka, B., Pasteris, J.D., 1993. Structural characterization of kerogens to granulite-facies graphite : applicability of Raman microprobe spectroscopy. Am. Mineral. 78, 533-557.

Yelland, A.J., 1991. Thermo-tectonics of the Pyrenees and Provence from fission track studies. Ph.D. thesis, University of London.

\section{Figures captions}

study area is located in the eastern part of this belt.

Figure 2: Geological map of the eastern part of the North Pyrenean Zone (localization on Fig. 1) (after Crochet et al., 1989; Berger et al., 1997; Bles and Berger, 1982; Fonteilles et al., 1993) with $T_{\max }$ measured with Raman spectrometry (Chelalou, 2015 (in blue); Clerc et al., 2015 (in black) and this study (in red)) and thermobarometry estimates (Golberg and Leyreloup, 1990). Localisation of Mesozoic sequences remnants on the Agly massif are pointed out by numbers:

This article is protected by copyright. All rights reserved. 
1163 (1) Serre de Cors; (2) Serre de Verges; (3) Roc de Lansac; (4) Lake Caramany and (5) Agly

1164 dam.

1165 Figure 3: Isometamorphic map of the HT/LP metamorphism distribution in the eastern part of 1166 the North Pyrenean Zone.

1167 Figure 4: Structural map of the eastern part of the North Pyrenean Zone (localization on Fig. 1168 1) (after Crochet et al., 1989; Berger et al., 1997; Bles and Berger, 1982; Fonteilles et al., 1993).

1169 This map displays the different tectono-stratigraphic units and the detail of structural framework 1170 (trajectories of foliation and cleavage; lineations and folds). Early convergence-related fault are 1171 drawn in orange and late convergence-related fault in red.

1172 Figure 5: field photographs and interpretations of the observed deformation in the Paleozoic

1173 sediments of the Agly massif. a) top-to-the N normal shears. b) top-to-the S reverse shears.

1174 Figure 6: field photographs and interpretations of the observed deformation in Mesozoic Bas1175 Agly sedimentary cover. a) big picture on Rhaetian and Liassic sediments of the southern Bas1176 Agly, modified after Clerc et al. (2016). b) zoom on recumbent fold with top-to-the north 1177 verging. c) pure shear deformation and hectometer-scale boudinaged of Liassic sediments.

1178 Figure 7: Geological cross sections through the eastern part of the IMZ illustrating the 1179 relationships between the Bas-Agly syncline and surroundings units. Legend is similar to Figure 11802.

1181 Figure 8: Comparison of thermal structure for two endmembers: (a) a detachment system 1182 forming a MCC and (b) a thrust system. Structures are sole in the middle-lower continental 1183 crust and isotherms represent static maximum temperatures reached by rocks.

1184 Figure 9: Geodynamical model of the eastern part of the NPZ illustrating a structural evolution 1185 from the rifting event to the present, modified after Ternois et al. (2019). Four steps of This article is protected by copyright. All rights reserved. 
1186 restoration are depicted. SFPT: South Pyrenean Frontal Thrust; NPF: North Pyrenean Fault;

1187 LTFF: La-Tour-de-France Fault; TF: Tautavel Fault; NPFT: North Pyrenean Frontal Thrust.

1188 See text for explanations.

This article is protected by copyright. All rights reserved. 


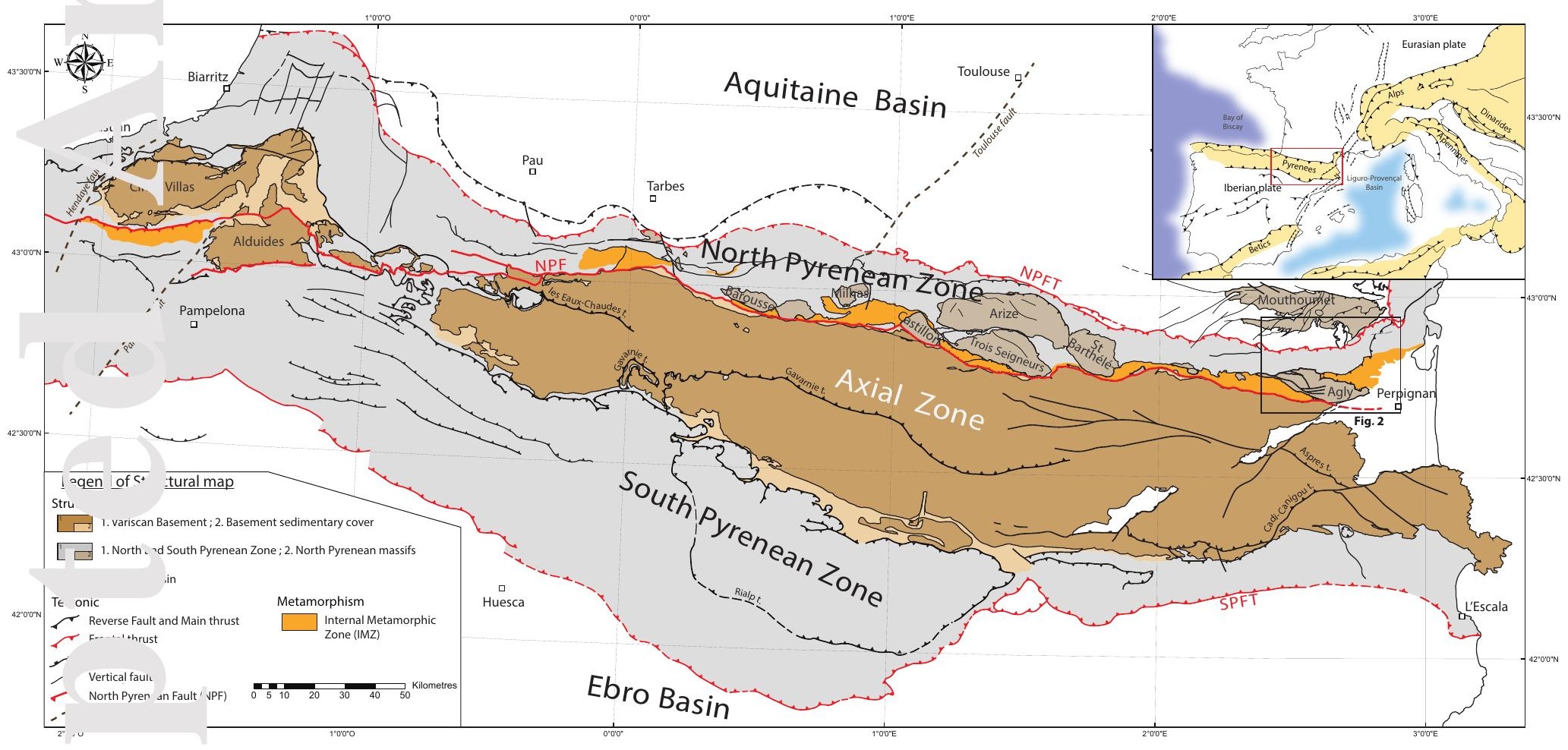

This article has been accepted for publication and undergone full peer review but has not been through the copyediting, typesetting, pagination and proofreading process, which may lead to differences between this version and the Version of Record. Please cite this article as doi: 10.1029/2020TC006512.

This article is protected by copyright. All rights reserved. 


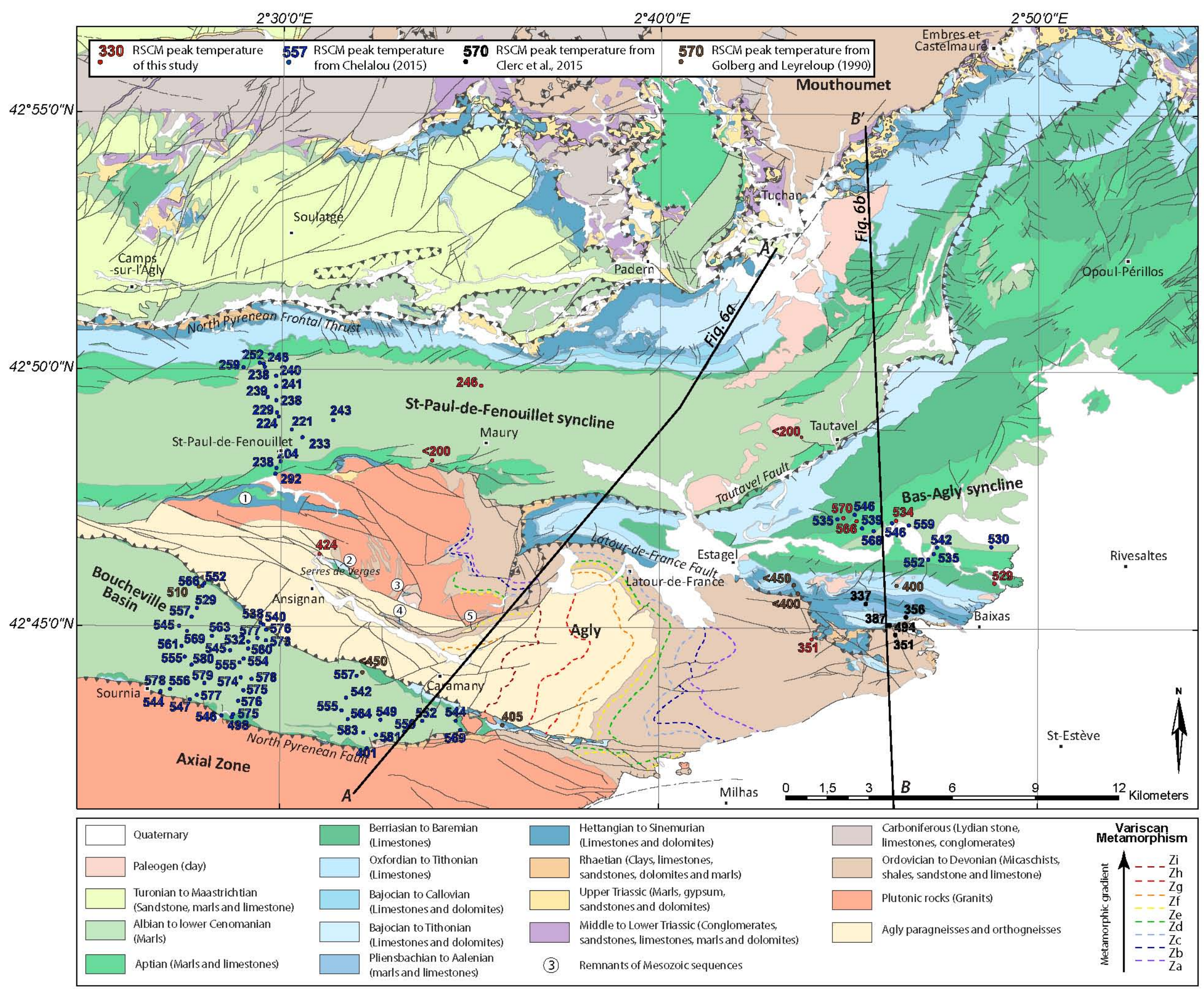



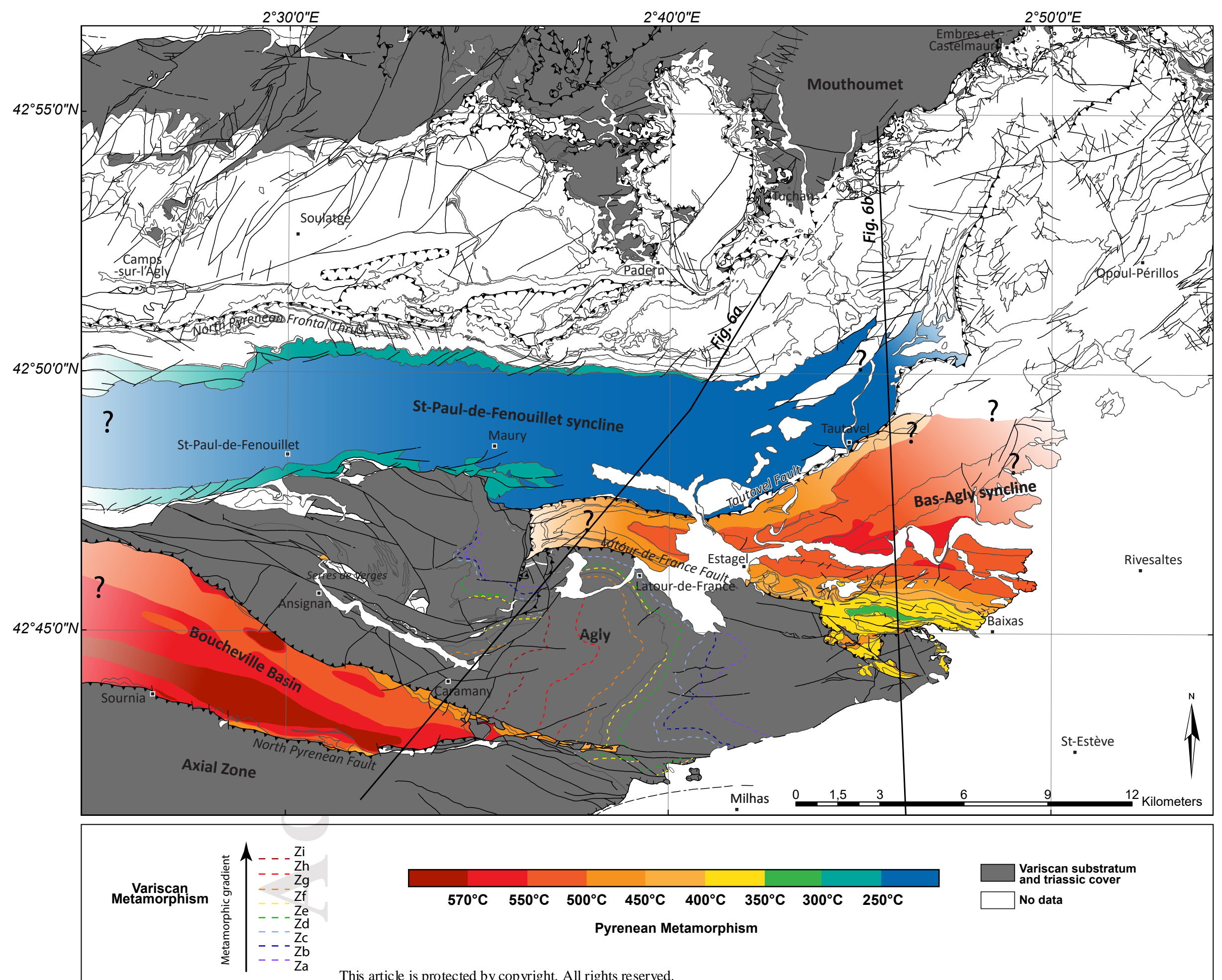

Variscan substratum
and triassic cover

No data

This article is protected by copyright. All rights reserved. 
Post-rift $\square$ Turonian to Maastrichtian Syn-rift $\square$ Albian to Cenomanian $\square$ Rhaetian to Aptian

Pre-rift $\{$ Upper Triassic and Ophite $\square$ Permian to middle Triassic Basement $\left\{\begin{array}{l}\square \text { Metasediments } \\ \square \text { Metamorphic rocks }\end{array}\right.$ $\square$ Plutonic rocks

\section{Details of structures}

- Pyrenean Structures

Structural data

$\checkmark\left(S_{0-1}\right)$ Direction trajectories of ductile foliation

$\checkmark\left(S_{2}\right)$ Direction trajectories of cleavage

- Cleavage front

₹ Stretching lineations

$\leftarrow$ Mineral lineations

$\longleftarrow$ ductile lineations (after Clerc et al., 2015)

Salt tectonic- related structures

$\bigcirc$ Diapiric zones and rafts

Faults

Main early convergence faults

$\longrightarrow$ Main late convergence faults

T. Minor thrusts

_ Undifferentiated faults

Late breccias (décollement plane?)

Folds

Large scale Synform

$\uparrow$ Large scale Antiform

$\sqrt{18}$ Local (dm to $\mathrm{m}$ ) folds with plunge value of axis - Variscan Structures

Thrusts and reverse fault

- Extensional fault

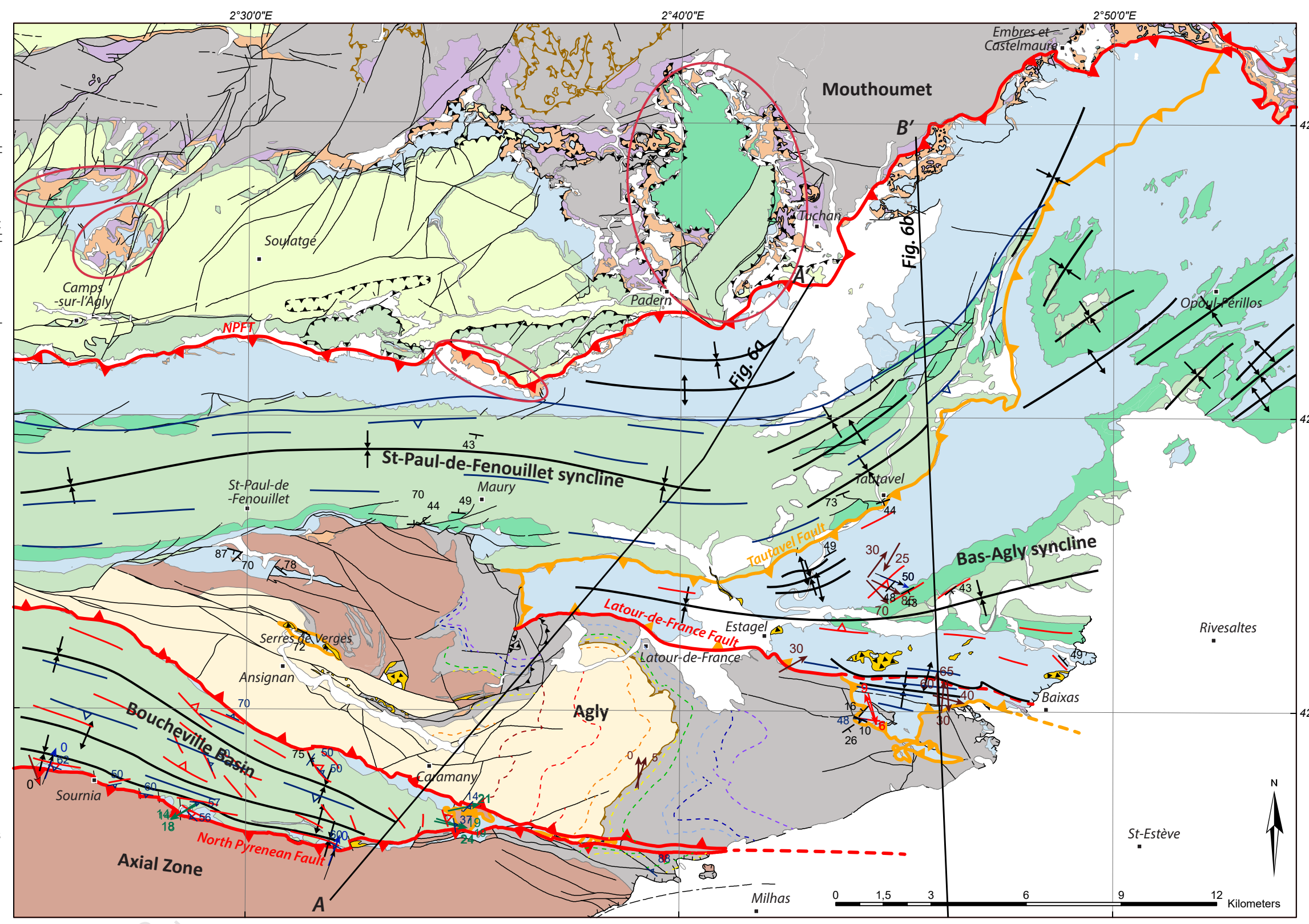

This article is protected by copyright. All rights reserved. 

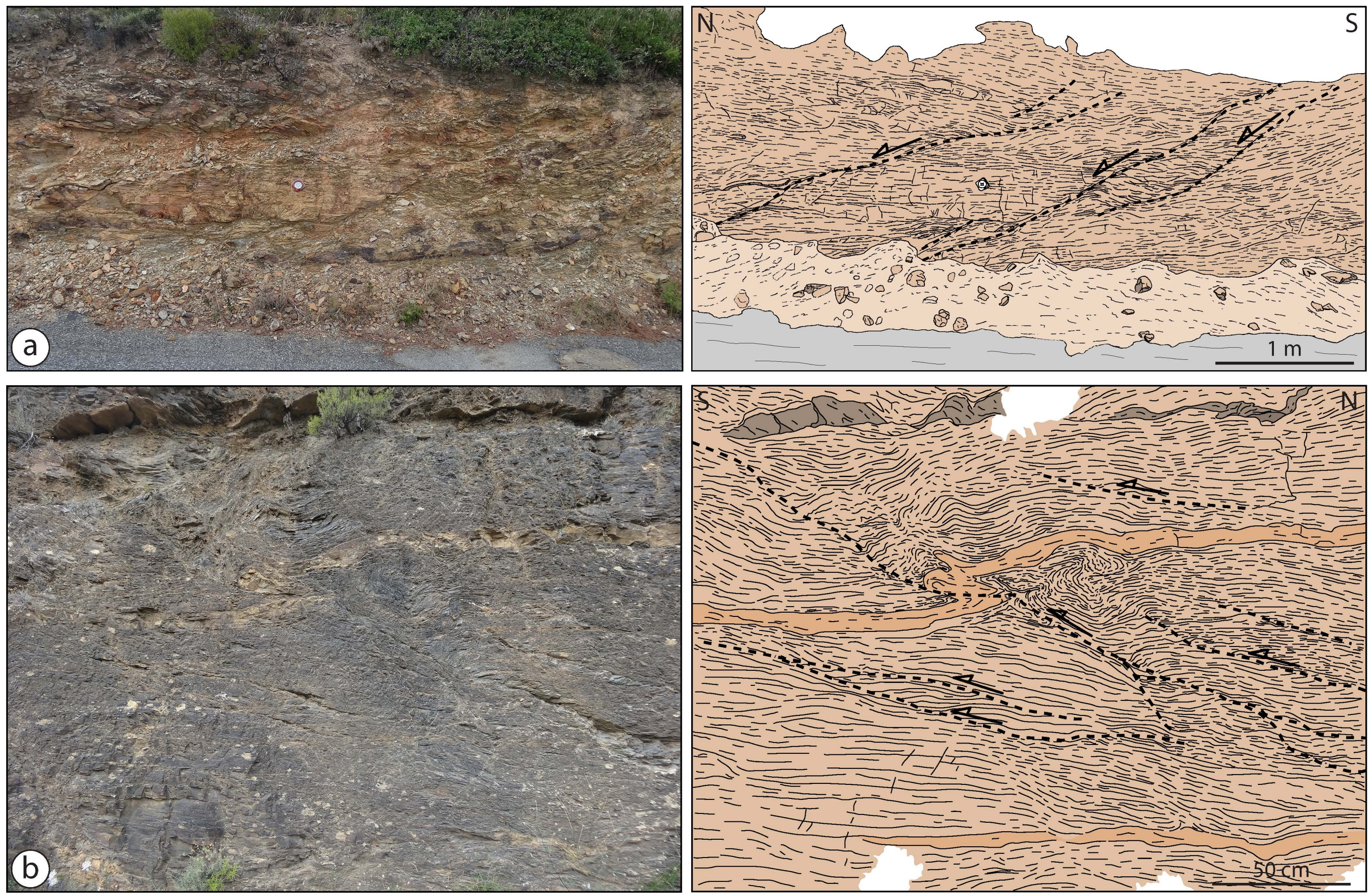

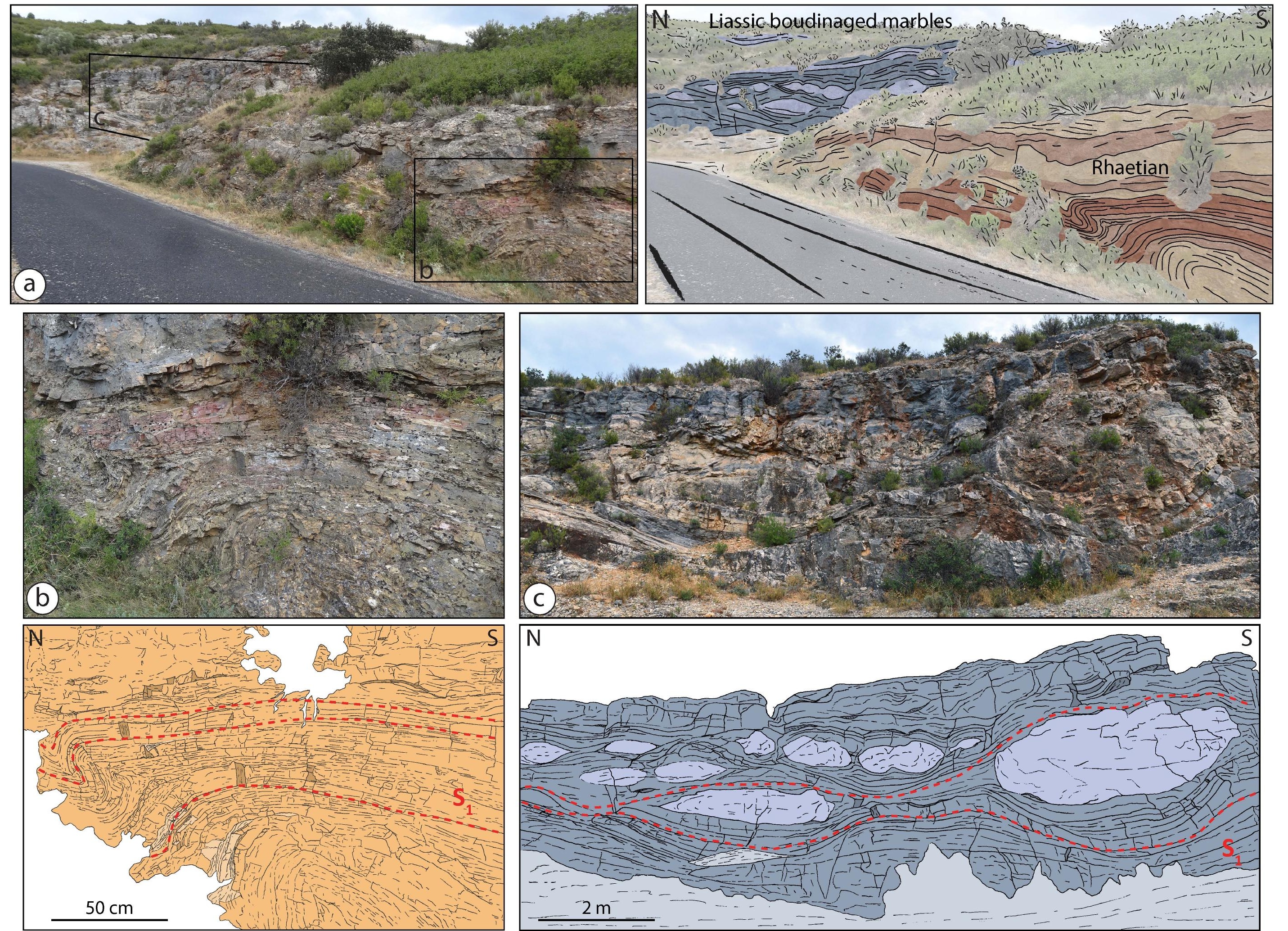


\section{SSW}

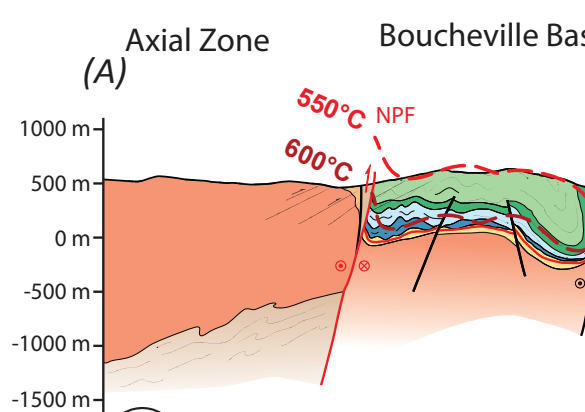

(a)

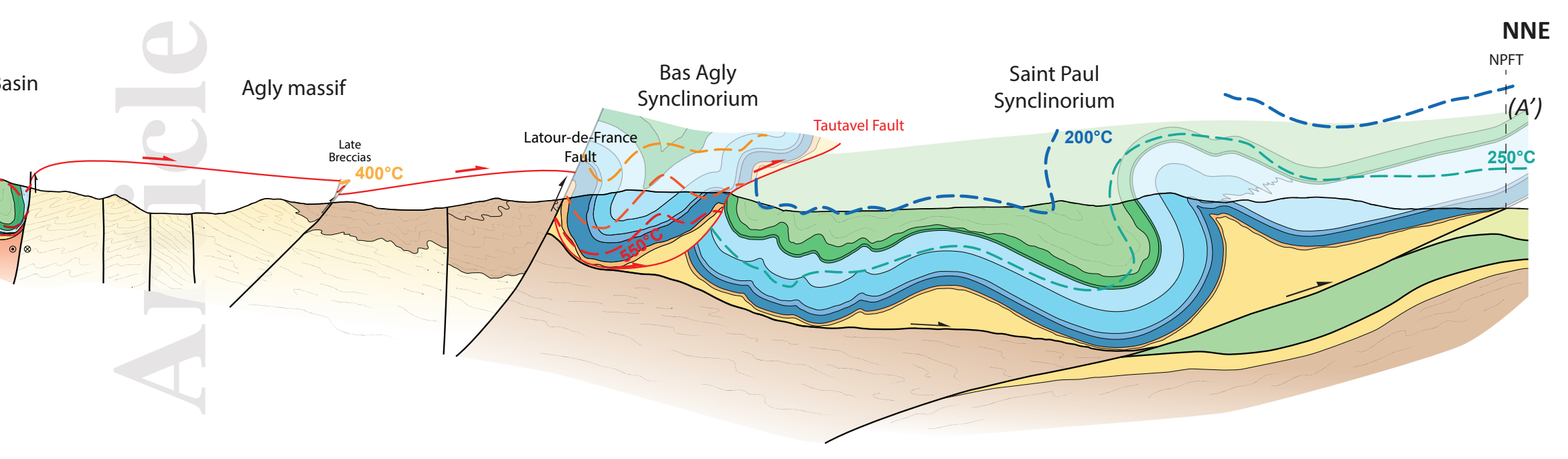

\section{$0.51 \mathrm{~km}$}

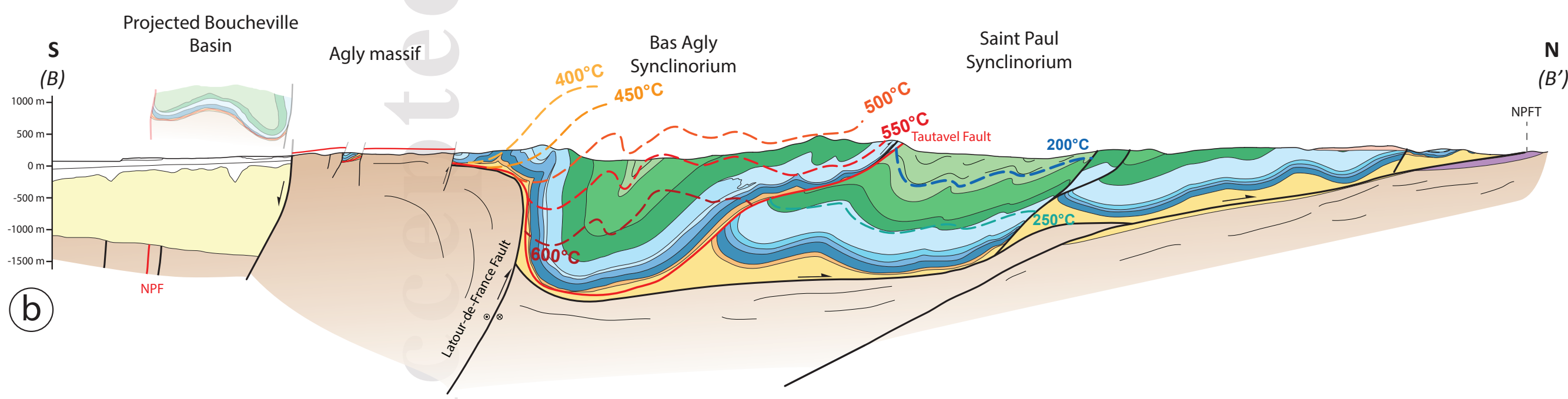


Typical thermal structure related to a Detachment system

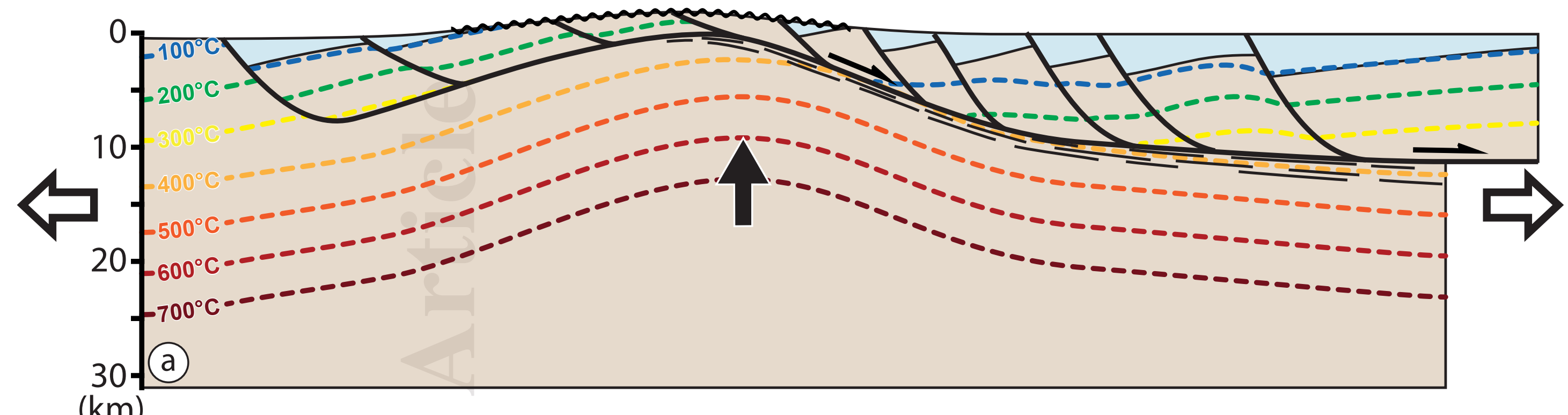

$(\mathrm{km})$

Typical thermal structure related to a Thrust system

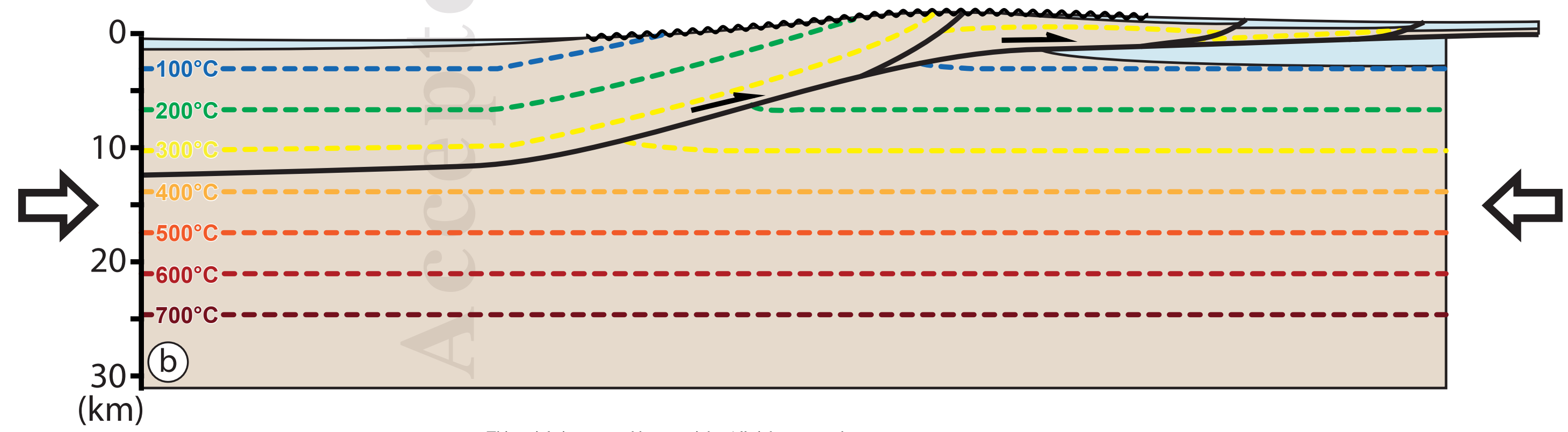

This article is protected by copyright. All rights reserved. 


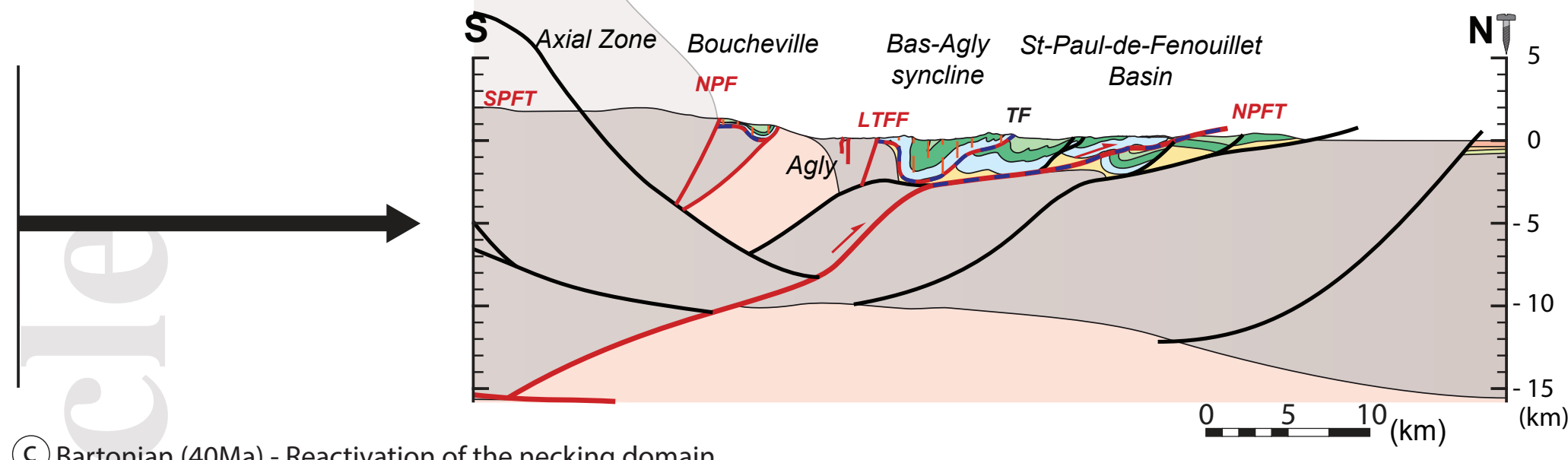

(C) Bartonian (40Ma) - Reactivation of the necking domain

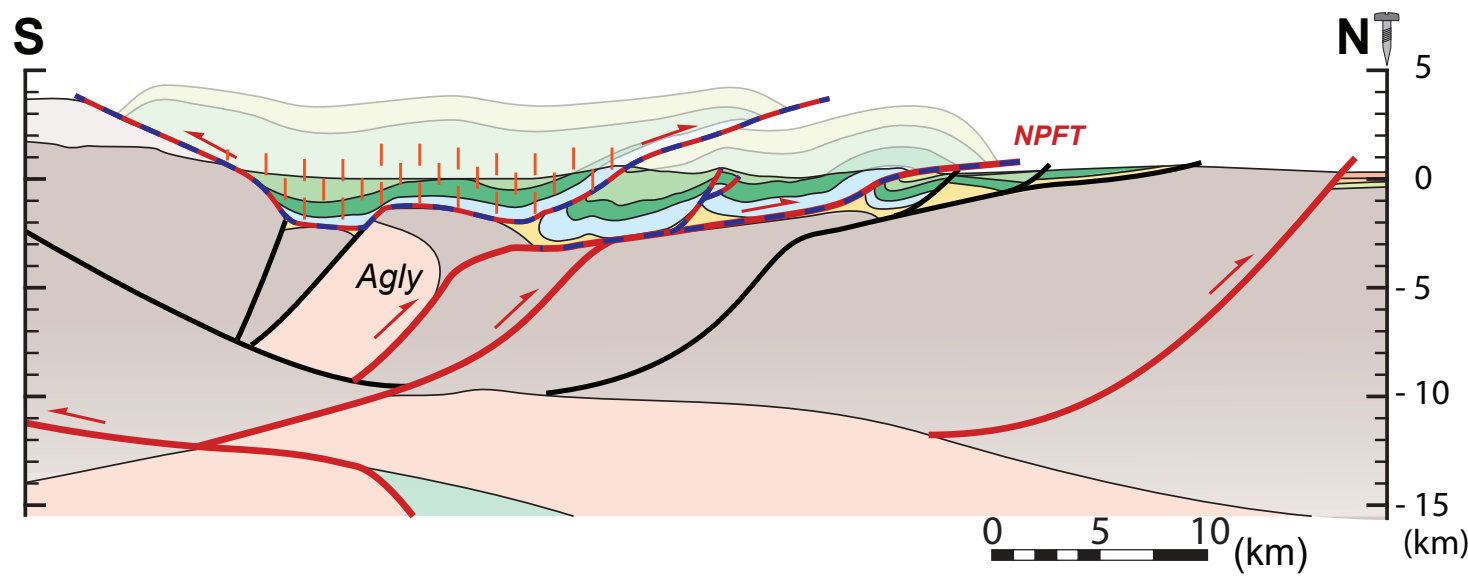

(b) Late Maastrichtian (66 Ma) - Early convergence

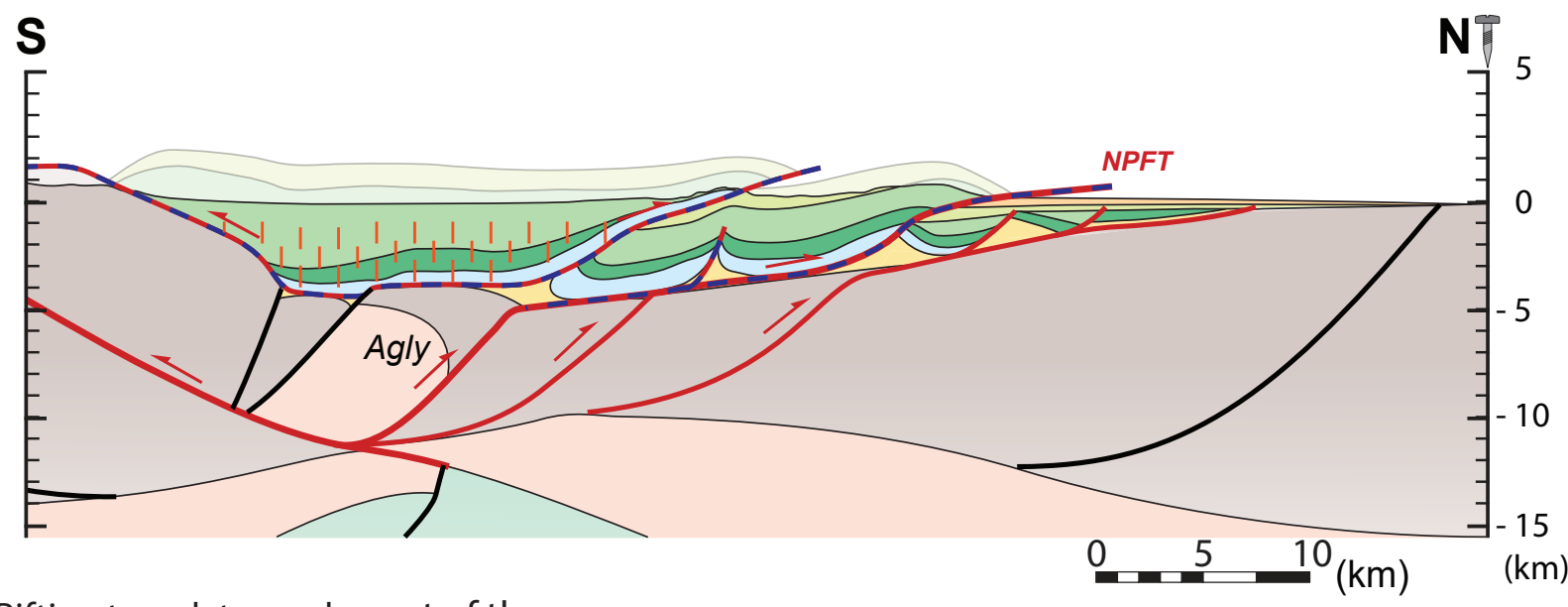

(a) Early Santonian (84 Ma) - Rifting templates and onset of the convergence

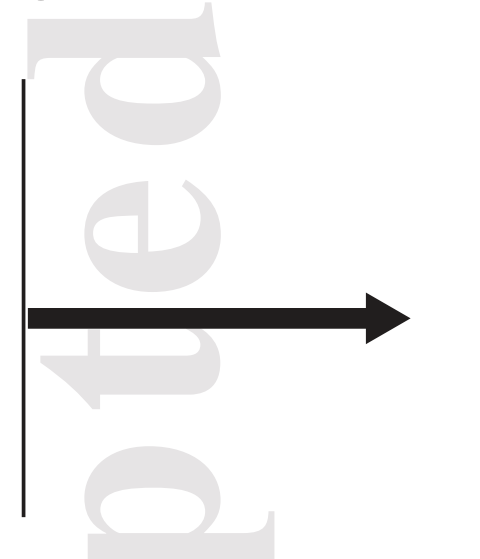

\section{Lithostratigraphic units}

Basement

$\square$ Lower crust

This artic

Pre-rift
$\square$ Jurassic
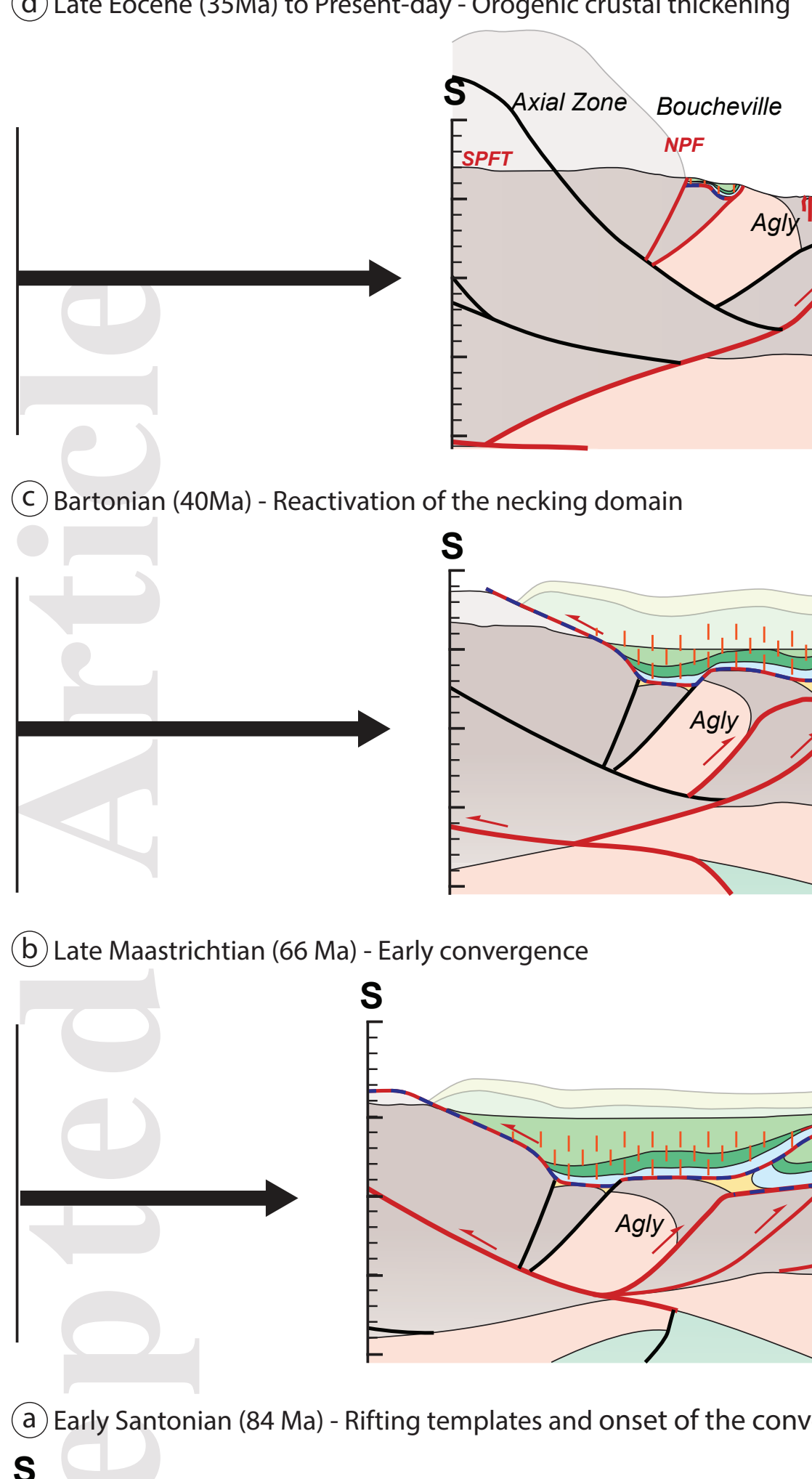

\section{$\square$ Lithospheric mantle}

\section{Unroofed}

sub-continental

mantle

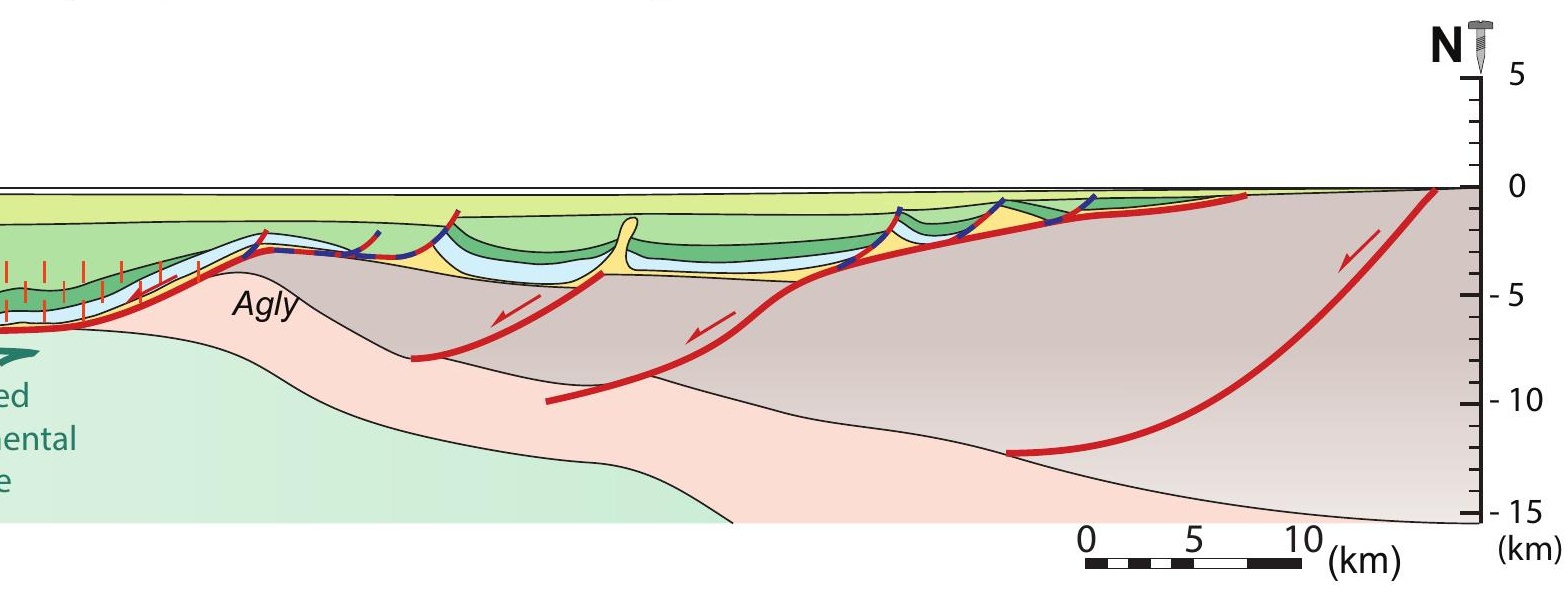

U. Upper Triassic

$\square$ Late Albian to mid-Cenomanian Early Aptian to early Albian
Metamorphism

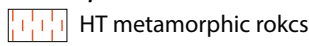

Tectonic

Abandoned faults

Active faults 